\section{Features of Second Life virtual environment and evaluation within the scope of art education}

Second Life sanal ortamının özellikleri ve sanat eğitimi kapsaminda değerlendirilmesi

\author{
Sevda Ceylan Dadakoğlu ${ }^{1}$ \\ Şeniz Aksoy ${ }^{2}$
}

Özet

Teknolojinin hızla ilerlemesine bağlı olarak eğitim ve öğretim alanında birçok ortam, araç ve yöntem geliştirilmektedir. $\mathrm{Bu}$ yeniliklerin içerisinde son yıllarda sıkça karş̧ılaştığımı sanal dünyalarda eğitim ve üç boyutlu eğitim teknolojileri de yer almaktadır. Üç boyutlu eğitim teknolojilerinin iyileştirilmesiyle beraber "3B sanal dünyalarda öğrenme"nin ön plana çıktığ bilinmektedir. Buna bağlı olarak eğitimin tüm kademelerinde, öğrenme ve öğretme sürecinde sanal ortamların işe koşulduğundan söz edilmektedir. Bu araştırmada üç boyutlu, çevrimiçi bir yaşam simülasyonu olan ve alternatif bir öğretim ortamı olarak tanımlanabilen Second Life sanal dünyası incelenmiştir. Bu makalenin amac1; sanat ve tasarım eğitiminde kullanılabilecek sanal ortamlardan Second Life's tanitmak, bu konuda teorik bir perspektif kazandırmak, 3B sanal dünyaları eğitim amaçlı kullanmak isteyen araşıtırmac1 ve öğretmenlere katk1 sağlamak ve bu ortamda yapılacak araştırmalar için kuramsal zemin oluşturmaktır. Bu nedenle öncelikle 3B sanal dünyalara genel bir çerçeveden bakılmışıtı. Ardindan 3B sanal ortamlardan Second Life

\footnotetext{
1 Ph.D., svdeylul@gmail.com (iD) Orcid ID: https://orcid.org/0000-0003-2583-6368

2 Prof. Dr., Gazi University, Faculty of Education, Department of Fine Arts Education, senizaksoy@gmail.com
} 
its general characteristics were defined.In addition, the use of Second Life in education, construction and content creation within the application, art and design making and art education were discussed. For this reason, examples of the artists using the Second Life application were given and some of the educational practices related to how Second Life was used in art and design education were included. In the conclusion part, with the development of technology and the use of virtual worlds in education, the gains that can be achieved in art classes were also included. In this context, the importance of the use of technology, various computer applications (VR, augmented reality applications, etc.) and 3D virtual worlds was mentioned in terms of today's art education gains. It was also stated that the ways of incorporating technology into art education should be questioned.

Keywords: Second Life; Art and design education; 3D design.

(Extended English summary is at the end of this document) uygulaması detaylı bir biçimde incelenerek genel özellikleri tanımlanmıştır. Second Life uygulamasının eğitimde kullanılması, uygulama dâhilinde inşa ve içerik oluşturma, sanat ve tasarım yapma ve sanat eğitimi konusu tartısılmıştır. Daha sonra Second Life uygulamasını kullanan sanatçlara örnekler verilmiş ve Second Life'in sanat ve tasarım eğitiminde nasıl kullanıldığına ilişkin eğitim uygulamalarından bazılarına yer verilmiştir. Sonuç kısmında teknolojinin gelişmesi ve sanal dünyaların eğitimde kullanımıyla beraber sanat derslerinde elde edilebilecek kazanımlar yer almıştır. Buna bağlı olarak teknolojinin, çeşitli bilgisayar uygulamalarının (VR, artırılmış gerçeklik uygulamaları, vb.) 3B sanal dünyaların eğitimde kullanılmasının günümüz sanat eğitimi kazanımları açısından önemine değinilmiştir. Ayrıca sanat eğitimine teknolojinin dâhil edilme biçimlerinin sorgulanması gerektiği ifade edilmiştir.

Anahtar Kelimeler: Second Life; Sanat ve tasarım eğitimi; 3B tasarım.

\section{Giriş}

İnsanın bütün edinimleri, eylemleri mevcut teknolojik yapılanmadan etkilenmektedir (Avc1 Tuğal, 2018, s.12). Son ylllarda köklü bir gelişme gösteren teknoloji, insan yaşamının birçok alanını olduğu gibi eğitimi de etkilemiştir. Sanal dünyaların eğitimde kullanımı ve uygulanması 1970'lerden başlayarak günümüze kadar gelmiştir (Inman, H. Wright, A. Hartman, 2010, s.67). 1980'lerin ve 1990'ların bilgisayar teknolojisindeki gelişmeler, internet tabanlı ortam olarak tanımlanabilen öğrenme sistemlerinin oluşturulmasına olanak sağlamıştır (Duncan, Miller, Jiang, 2012, s.2).

Sanal dünyalar, astronomi eğitiminden mimarlık eğitimine, dil eğitiminden tasarım eğitimine kadar birçok alanda kullanılabilmektedirler (Akt. Koçak, Demirel, Karakuş, Göktaş, 2016, s.41). Eğitimciler deneysel ve yapılandırmacı öğrenmeyi geliştirme potansiyelleri ile senkronize iletişim ve işbirliği için firsatlar sunduğundan 3B dünyaları araştırmaya yönelmiş ve bu dünyaları uzaktan eğitim için bir araç olarak kullanmıştır (Inman, H. Wright, A. Hartman, 2010, s.67-68).

3B sanal dünyaların; yapılandırmacı öğrenmeyi desteklediği (Dickey, 2003; Kluge ve Riley, 2008) etkili işbirlikçi öğrenmeyi sağladığ1 (Dalgarno ve Lee, 2010, Jacka, 2010; Warburton, 2009; Duncan, Miller ve Jiang, 2012) deneyimsel alan olarak kullanıldığ1 (Hew ve Cheung, 2008; Kluge ve Riley, 2008; Warburton, 2009, Dalgarno ve Lee, 2010) birçok araştırmacı tarafindan ifade edilmiştir. Sanal ortamların öğrenme ve öğretme konusundaki üstün ve zayıf yönleri sıcça araştırılmış (Sherblom,Withers ve Leonard, 2009; Çoban, Kalkan ve Hinısoğlu, 2017) sanal öğrenme ortamlarının, öğretme ve öğrenmeyi destekleyerek olumlu öğrenme sonuçları doğurabileceği, çeşitli pedagojik faydalar sağlayabileceği görülmüştür (Duncan, Miller ve Jiang, 2012; Clark ve Mayer, 2011; Mikropoulos ve Bellou, 2006, Dalgarno ve Lee, 2010). 
Ayrıca sanal dünyalar, çeşitli potansiyel araştırma ve geliştirme alanları olarak tanımlanmış (Warburton,2009; Duncan, Miller ve Jiang, 2012) hem K-12 hem de yükseköğretimde nasıl kullanıldığı incelenmiş (Inman, H. Wright ve A. Hartman, 2010) ve çeşitli eğitim disiplinlerinin kullanılmasına olanak sağlayan bir platform olarak görülmüştür (Warburton, 2009). Bir öğretme ve öğrenme ortamı olarak sanal dünyaların çok kapsamlı olduğu ve pek çok öğrenci için motive edici olabilecek yeni bir deneyim olduğunu söylenmektedir. Karmaşık öğretim stratejilerinin, rol oynama ve simülasyon gibi etkinliklerin sanal dünya için oldukça uygun olduğu belirtilmektedir (Jacka, 2010, s. 138).

Okuma yazma biçimleri ve işlevleri hızla değişen bugünün postmodern dünyasında, farklı iletissim alanlarındaki multimedya akıcılı̆̆1; video, resim, müzik ve dans, bilgisayar dilleri, internet aracılloğıla gündelik konuşma ve oyunların yanı sıra yazılı basımı da içeren çoklu okuryazarlıklara doğru genişlemiştir (Thomas'dan aktaran Stokrocki, 2011). Üç boyutlu bilgisayar teknolojilerinin gelişimi ile birlikte ögrrenme ortamlarında 3B sanal dünyalar, sanal gerçeklik (Virtual Reality), artırılmış gerçeklik gibi ortam ve araçlar kullanılmaya başlanmıştır. Stokrocki (2011), elektronik iletissim araçları kullanılarak oluşturulan dijital medyanın, eğitimde bir paradigma değissimi olarak bizleri çevrelediğini söylemektedir. Gelecekte, sanat öğretimindeki dijital dünyaların potansiyelinin uçsuz bucaksız olduğunu söyleyen Stokrocki, Second Life'nn sanat eğitiminde kullanılabilirliği konusunu tartışmış, 2012 yılında Sanal Dünyalarda Dijital Etnografya adlı bir kurs geliştirmiştir (ASU,2019).

Han (2009), Second Life ve diğer sanal platformları alternatif bir eğitim ortamı olarak kullanmıştır. Ayrıca Han (2015, s.257) 3-B animasyon öğrenmeye öğrencinin ilgisini artırmak ve 3-B profesyonel öğrenme yazılımıyla ilgili öğrenci korkularını azaltmak için "Gamified” pedagojiyi kullanmaktadır. "Oyunlaştırılmış bir pedagojiyle, öğrencilerin ders içeriğginden ve birbirlerinden daha fazla şey öğrenmekle ilgilenen kendi kendine motive olan öğrenciler olabileceği” sonucuna varmıştır. Han, sanal ortamlarda sanat ve tasarım eğitimi ve görsel kültürle ilgili birçok araştırma yapmıştır.

Günümüzde teknoloji, öğrencileri motive edebilen ve kendilerine özgü katkılar sağlayacak senaryolar sunabilen bir araç olarak tanımlanmaktadır. Teknoloji aracılı öğrenme ortamları gittikçe daha interaktif, eş zamanlı ve esnek hale gelmektedir (Niemi vd, 2014, s. 658-660). Sanat eğitiminde ve bu alanda öğretmen yetiştirmede teknolojik deneyim ve uygulamaların önemi daha fazla vurgulanmaktadır (Tillander, 2011'den aktaran Mamur, 2014, s.63).

Ülkemizde genel eğitim içerisinde Bulu ve İşler (2011), Doğan, Göktaş, Küfrevioğlu ve Reisoğlu (2011), Uzun, (2011) sanal dünyalarla ilgili çalısmalar yapan araştırmacılardan bazılarıdır. Ocak'1n (2013) editörlüğünü yaptığı "Eğitsel Dijital Oyunlar" isimli kitapta dijital oyunların eğitimsel olarak öğrenmeye olan etkileri birçok araştırmacı tarafindan incelenmiştir. Göktaş'ın (2017) editörlüğünü yaptığ1 "Üç Boyutlu Sanal Dünyaların Eğitimde Kullanımı" isimli kitapta araştırmacıların farklı sanal dünyaları farklı açılardan irdeledikleri görülmektedir.

Ülkemizde özellikle son zamanlarda bazı sanat ve tasarım eğitimi araştırmacılarının (örneğin; Tasa (2009), Gül, (2011); Bülbül, (2016); Ceylan Dadakoğlu, (2018)'nun) ilgisini çeken sanal ortamlar ve eğitim konusunun genel çerçevesinin çizilmesi gerekmektedir. Bu makalenin amacı; sanat ve tasarım eğitiminde kullanılabilecek sanal ortamlardan Second Life'ı tanıtmak, bu konuda teorik bir perspektif kazandırmak, 3B sanal dünyaları eğitim amaçlı kullanmak isteyen araştırmacı ve öğretmenlere katkı sağlamak ve bu ortamda yapılacak araştırmalar için kuramsal zemin oluşturmaktır.

\section{1. Araştırmanın Modeli}

\section{Yöntem}

$\mathrm{Bu}$ araştırmada betimsel tarama yöntemi kullanılmışır. Bu çerçevede ilgili alanyazın incelenmiş kuramsal-çözümleyici bir yol izlenmiştir. Betimsel araştırmalar genellikle verilen bir durumu dikkatli bir şekilde tanımlama, değerlendirmeler yapma ve olaylar arasındaki ilişkileri ortaya koyma amacını taşır (Çepni, 2007, s.34). Bu çalışmada öncelikle 20. yüzyılın son çeyreğinden itibaren 
elektronik ve dijital teknolojinin gelişiminin eğitimle olan ilişkisi sorgulanmıştır. Daha sonra sanal dünyalardan Second Life sanal dünyası hem kendi içinde hem de sanat ve sanat eğitimi açısından detaylı bir biçimde incelenmiştir. Second Life sanal dünyasının eğitim bağlamında genel çerçevesi çizildikten sonra eğitimde uygulama biçimlerine yer verilerek sanat ve tasarım örnekleri verilmiştir. Daha sonra Türkiye'de bu sanal platformun kullanılabilmesi için değerlendirme ve önerilerde bulunulmuştur.

\section{Bulgular}

Uluslararası düzeyde sanat ve tasarım eğitimi alanında elde edilen son dönem görsel ve yazılı kaynakların incelenmesiyle ulaşılan bulgular bağlamında, sanal dünyalar ve Second Life sanal dünyası genelde eğitim özelde ise sanat ve tasarım eğitimi açısından incelenmeye çalışılmıştır. Ayrıca Second Life'ta yer alan bazı sanat pratiklerine ve sanat ve tasarım eğitiminde kullanılma biçimlerine yer verilmiştir.

\section{1. Sanal Dünyalar}

Goodman, "Semboller kullanılarak hiçlikten sayısız dünyalar yapıldı." (Wilson, 2011). 20. yüzyllın son çeyreğinden itibaren elektronik ve dijital teknoloji sadece yeni bir teknoloji olarak kalmamış ortamın kendisi dijital olmuştur. 21. yüzyılla birlikte gerçek dünya ve sanal dünya arasında yaşamaya başlayan insan varlığını her iki dünyada da sürdürmek zorunda kalmıştır (Avcı Tuğal, 2018, s. 13). Sanal ortamlar sadece gerçekliği taklit değil, aynı zamanda kullanıcıların birlikte yeni bir gerçeklik oluşturabilecekleri yerler olarak tanımlanmaktadır (Burbules'tan aktaran Han, 2016, s.1). Dickey (2005, s.439) sanal dünyaları, kullanıcıların üç boyutlu (3B) ortamlarda hareket ettiği ve etkileşimde bulunduğu dijital alanlar olarak tanımlamıştır.

Acaroğlu (2010), metin tabanlı ve grafik tabanlı olarak sinıflandırılabilen sanal dünyaların kökeninde, sadece yazılı komutlar üzerine kurulmuş bir sistem şeklinde oynanan ve günümüzde yaygınlığını yitiren MUD’lerin (Multi User Domain) yattı̆̆ını söylemektedir. MUD’lardan sonra ise MOO (Multi-user Domain Object Oriented) ve MMORPG'larin (Massive Multi-Player Online Role Playing Game-Kitlesel Çevrimiçi Rol Yapma Oyunu) gelişimine tanık olunmuştur (Soyseçkin, 2007, s. 30).

Hem görsel hem de sosyal içeriğin, sakinler tarafindan tasarlandığı üç boyutlu bir sanal dünya fikri ilk olarak 1992' de Neal Stephenson'ın “Snow Crash” isimli bilim-kurgu romanında kullandığ1 "Metaverse" kavramiyla ifade edilmiştir (Ondrejka, 2004, s.2). "Metaverse" sözcüğü Yunanca "meta" ön eki ile İngilizce "universe" sözcüklerinin bir araya getirilmesiyle oluşturulmuştur. Smart, Cascio ve Paffendorfa (2007) göre "Metaverse" kavramı, üç boyutlu sanal dünya öngörüsü olarak fiziksel dünyanın nesnelerini, arayüzlerini, ağlarını sanal ortamını inşa eden ve onlarla etkileşimi sağlayan bir öngörü olarak anlam kazanmış ve Stephenson'un 1992 vizyonunun ötesine geçmiştir. "Snow Crash" sonrasında birçok sanal dünya tasarlanmıştır. "Metaverse" fikrinden yola çıkarak temelleri atılan "There", "Active Worlds" ve "Second Life" gibi 3B sanal dünyaların varlı̆̆ bilinmektedir.

Sanal dünyalar, insanların kendilerini görüntülü olarak temsil edebilmesini sağlamakta ve kullanıcı etkileşimiyle farklı duyulara hitap edebilmektedir. Kullanıcıda ortamda bulunma hissi oluşturabilmekte, gerçek zamanlı doğal yönlendirmelerle sezgisel etkileşim sağlayabilmekte, güvenli bir ortam oluşturmakta ve bu şekilde sanal dünyanın daha görsel ve gerçekçi hale gelmesini sağlamaktadır (Mikropoulos \& Bellou, 2006, s.122-123). Sanal gerçeklik; askerlikte savaşa hazırlık uygulamalarında, uygulamalı tıp eğitiminde, mühendisliğin çeşitli alanlarında, yabancı dil eğitiminde, eğlence, tedavi, sanat, rehabilitasyon, finans ve eğitimde çok geniş bir alana ve kitleye hitap edebilmekte ve yaygın olarak kullanılmaktadır (Kayabaşı, 2005, s.157).

Günümüzde sanal dünyaların kullanım amaçları gittikçe çeşitlenmektedir. Sanal dünyalarda görsel ortamlar yaratabilmekte, çeşitli $2 \mathrm{~B}$ ve $3 \mathrm{~B}$ tasarımlar yapabilmekte, bu dünyalar yaşam simülasyonu olarak kullanabilmekte, eğitime sanal dünyalar dâhil edilmekte ve sanal dünyaların yapısına göre yeni bakış açıları denenebilmektedir. 


\section{2. Second Life}

2003 yllında Linden Lab tarafindan kamuya açıklanan Second Life, 1999 ylında kurulan San Francisco merkezli bir şirket olan Real Networks' ün eski teknik uzmanı Philip Rosedale tarafindan geliştirilmiş 3B sanal bir dünyadır. Aslında fizikçi olan Rosedale, Second Life'ı geliştirirken Neal Stephenson'ın "Snow Crash" isimli romanından esinlendiğini belirtmektedir. Stephenson'ın kitab1, her şeyi sayısal ortama aktarmanın mümkün olduğunu iddia etmesi ve siberpunk tarzındayazılan bir roman olması nedeniyle önem taşımaktadır (Jennings ve Collins, 2007, s.181).

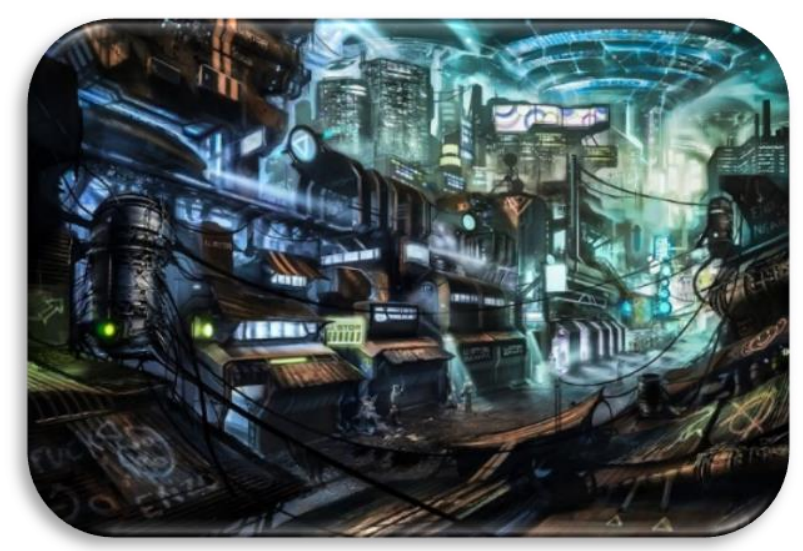

Şekil 1. Snow Crash'ta yer alan "Büyük Hong Kong” şehrinin Igor Sobolevsky tarafindan yapılan bir illüstrasyonu. Manisalı, A. (2016). Neal Stephenson-2: Snow Crash and Metaverse. http://heran.org/2016/07/neal-stephenson-2/ html sayfasından erişilmiştir.

Second Life, "There" ve "Active Worlds" ün açtı̆̆ yoldan gitmekle beraber tamamen kullanıcı yaratımı bir dünya oluşturma hedefiyle yola çıktığı için, yarattı̆̆ çevrimiçi üç boyutlu dünya Metaverse hayalîyle en fazla özdeşleştirilen ve benzerleri arasında en ünlü olan dünyadır. Rosedale, Second Life ile bir oyun tasarlamadığını, yeni bir ülke yarattığını söyler (Jennings ve Collins'ten aktaran Uzun, 2011). Second Life, gerçek dünyaya alternatif olabilecek bir ütopya olarak tasarlanmıştır (Harrison, 2009, s. 85).Second Life Turkey'in (2019) açıklamaları içerisinde; gerçek hayata olabildiğince yakın tasarlanan, internet ile bütünleşen ve internetin tüm olanaklarını kullanıcılarına sunabilen, 3B görsel bir arayüze sahip, çevrimiçi yaşam simülasyonu olan Second Life, 3B internet olarak ta tanımlanmaktadır.

Second Life'ın sakinleri, World of Warcraft, The Sims Online gibi pek çok diğer internet tabanlı MMO ile benzer bir biçimde internet üzerinden bu dünyaya bağlanmakta ve kendilerini "avatar" adı verilen sanal kimliklerle ifade etmektedirler. Avatar kelimesinin dilimizdeki karşıllğı incelendiğinde; Türk Dil Kurumunun; sanal ortamlarda kullanıcıların kendilerini temsil etmesi için kullandıkları simge, Hint mitolojisine göre; tanrıların dünyaya indiklerinde büründükleri şekiller olarak tanımladığı görülmektedir (Türk Dil Kurumu,2019). Second Life’ta kullanıcıların sanal görünüm ve kimlikleri yani avatarları genelde insan formundadır. Kullanıcılar avatarlarını canlı veya cansız istedikleri forma sokabilmekte, var olan şablon avatarları ise istedikleri gibi değiştirip giydirebilmektedir. Kullanıcılar avatarlarını, yön tuşları ve ekranda ikonu bulunan oklarla hareket ettirmekte, dünya üzerinde herhangi bir adaya 1şınlayabilmektedirler. 


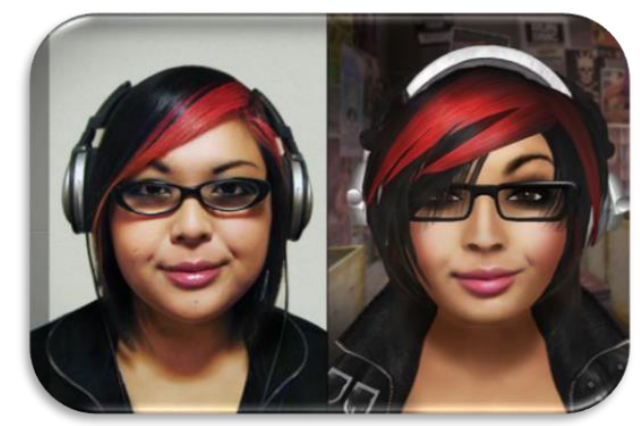

Şekil 2. Second Life Avatar görsellerinden bir örnek. http://go.secondlife.com/landing/avatar/ sayfasından erişilmiştir.

Second Life'ın sunduğu standart avatarlar sürekli yenilenmektedir. Ayrıca üç boyutlu biçimlendirme programlarında avatar tasarlanabileceği gibi Second Life içerisinde yer alan marketlerden istenilen türde vücut ve yüzler satın alınarak avatarlar özelleştirebilmektedir. Kullanıcılar Second Life ortamında sosyal, kültürel, eğlence amaçlı birçok etkinlik yapabilmekte ve gerçek bir hayat deneyimi yaşayabilmektedir. Second Life haritası, başlangicindan itibaren kullanıcıların Linden Lab'in sunduğu sanal arsalar üzerinde, üç boyutlu modelleme programları kullanarak yarattıkları ve sanal dünyaya ekledikleri eşyalar ve binalar ile yapılanarak genişlemiş ve hâlâ genişlemektedir.

Second Life, bilgisayarlı iletişim teknolojilerinin geldiği son aşamaları yansıtan 3B bir uygulamadır. Kullanıcıların; alternatif ve ütopik bir dünya yaratmalarına, insanlarla gerçek dünyadaki gibi etkileşime girebilmelerine, gerçek dünyadakine benzer davranışlar sergilemelerine olanak sağlamaktadır. Second Life, kullanıcıların istediği müziği dinleyebilmeleri, eğlenceli aktivitelerde bulunabilmeleri, yabanc1 dillerini geliştirilebilmeleri, istediği rolleri oynayabilmeleri, para kazanabilmeleri gibi özellikleriyle ve ayrıca görsel açıdan zengin üç boyutlu içerik ile diğer çevrimiçi ortamlardan ayrilmaktadır (Uzun ve Aydın, 2012, s. 265).

Kasım 2018 tarihinde elde edilen verilere göre;_Second Life 56,788,423'e ulaşan aktif kullanıc1 sayısıyla, en fazla tanınırlığı olan metaverse denemesidir (gridsurvey.com, 2018) Second Life'ın 2003 yıllından bugüne 1.1.3’ten başlayarak 5.0.2' ye kadar çok sayıda sürümü geliştirilmiştir. Second Life 'ta "Pasifik Standart Saati" (PDT) kabul edilmiş; 2005 yllinda ise Linden kambiyosu kurularak USD-Linden Dolar (Second Life para birimi) döviz değişiminin gerçekleşmesi mümkün olmuştur. 2017'de teleport konumları, komut dosyası, hata simgesi gibi alanlarda yeni düzenlemeler getirilmiştir.

Second Life'ın bir diğer özelliği de, gerçek gün ve gece döngüsünün olması, hava durumu sisteminin olması gibi gelişmiş teknolojileri yansıtmasıdır. Sanal dünyalar içerisinde, avatarların, kendi topluluklarıyla yazışabilmelerine olanak sağlayan sohbet kanalları, avatar sanal dünyaya giriş yaptığında kendisine bırakılan mesajları okuyabildiği e-posta sistemleri, sözsüz iletişim kurmasına olanak sağlayan beden dili ve mimikler (el sallamak, ağlamak, gülümsemek vb.) yer almaktadır. Second Life'ta ise bunlara ek olarak not kartları (notecards) aracilığyla da iletissim yapılmaktadır. Not kartlar genellikle nesneler ile ilgili bilgi veren kılavuzlar olarak tanımlanabilir veya uzun mesajlar göndermeye yarayan bir e-posta kutusu gibi kullanılmaktadır. Ayrıca Second Life sesli sohbete olanak sağlayan bir mikrofon sistemi de bulundurmaktadır.

18 yaşın alındaki kullanıcılar için oluşturulmuş olan Teen Second Life, genç kullanıcıları Second Life'ta yetişkinlerin kullanabileceği içeriklerden koruma amacı gütmüştür. 2005 yılının Şubat ayında açılan Teen Second Life, 2011 yılının Ocak ayında kapatılmıştır. Bunun yerine 18 yaş altı kullanıcılar için bazı kısıtlamalar (Linden evlerine girememek vb.) getirilerek Second Life'ın kullanılmasına izin verilmiştir. (Wiki Second Life, 2019). 
Linden Lab 2017 yılında Second Life üç boyutlu sanal ortam uygulamasını bir adım ileriye taşıyarak giderek daha popüler olan VR (Virual Reality) platformuna SANSAR adı altında uyumlu hale getirmiştir (lindenlab.com, 2019). Birçok VR uygulamasına destek veren Oculus Rift SANSAR uygulamasına teknik destek sağlamaktadır.

\section{2. 1. Ekonomik Yap1 ve İstatistikler}

İlk kurulduğunda 3 milyon dolar sermayeye sahip olan Second Life'in 2019 yllı piyasa değeri bilinmemektedir. Second Life'ta "Linden Doları" olarak adlandırılan para birimi geçerlidir (Ortalama 1 Amerikan Doları 262 Linden dolarına eşdeğerdir). Bu para birimi gerçek Amerikan doları ile değiştirilebilir olduğu için Second Life’taki ekonomik pazar sanal bir pazar olmaktan öteye geçerek gerçek bir piyasa ekonomisi oluşmuştur. Second Life ekonomisi, toprak ve serbest piyasa üzerine kurulu bir ekonomidir (slturkey.com, 2018).

Second Life'ta tasarım yapmak için ücret ödenmesine gerek yoktur. Yapılan tasarımların belli bir arazi üzerinde kalması isteniyorsa, arazi satın alınmalıdır veya herhangi bir arazi sahibi, tasarımı arazi üzerinde tutabilmek için tasarımciya izin vermelidir. Bir arazi sahibi olmayan kullanıcılar, "sandbox" adı verilen ücretsiz alanlarda inşa denemeleri yapabilmektedir. Yapılan tasarımlar Second Life tarafindan silinmektedir bu nedenle kullanıcıların tasarımlarını envanter (inventory) adı verilen ve kendilerine ait olan sanal klasöre kaldırmaları gerekmektedir. Bundan dolayı kullanıcıların tasarımlarını sergilemek veya satmak istemesi durumunda arazi satın almaları veya kiralamaları gerekmektedir.

Second Life'ta kullanıcıların kendi tasarladıkları nesneler, mimik ve jestler, sundukları hizmetler vb. gelir elde edebilecekleri tasarımları satışa sunmaları Second Life ekonomisinin temellerindendir. Avatarların dış görünüşleri için tasarlanan saç, kıyafet, aksesuarlar, mimik, jest hareketler için oluşturulan animasyonlar, taşıt ve bina tasarımları, para karşllŏı sunulan eğlence ve oyun mekânları gibi çok çeşitli parayla alınıp satılan tasarım ve hizmet imkânları bulunmaktadır (Tasa, 2009, 14).

Second Life'ın bir diğer gelir kaynağı olan premium üyelik bedeli, aylık 9,50 USD, üç ayda bir 22.50 USD ya da yılda 72 USD şeklindedir. Second Life sakinleri bu sanal dünyaya ücretsiz ilk kayıtlarını yapabilirler. Bu durumda Second Life'ta arsa alınamamakta ama arsa sahiplerinden kiralanabilmektedir. Premium üyelikte ise ada dâhil her tür toprak satın alınabilmekte, Second Life tarafindan her hafta 300 L\$, bir defaya mahsus olan 1000 L \$ hediye kaydolma bonusu, Linden Evi ya da Anakara üzerindeki parsellerde kullanılmak kaydıyla $1024 \mathrm{~m}^{2}$ arsa payı, olanakları iyileştirilmiş canlı sohbetli müşteri desteği, sürpriz sanal hediyeler, kişisel üyelik alanlarına ve deneyimlerine erişimde ayrıcalık, kaçırılan mesajlar için artırılmış kota, artırılmış grup üyeliği kotaları, ses biçimlendirme hizmeti, avatar yoğunluğu olan bölgelere öncelikli giriş gibi ayrıcalıklar tanınmaktadır (Second Life, 2019).

Second Life' ta ekonomik pazarın önemli noktalarından birisi de arsa ekonomisidir. Second Life'ta sanal kazancı gerçek hayata aktarmak ta mümkündür. Örneğin, 2006 yılında Second Life'ın ilk milyoneri şeklinde basın haberleri ile gündeme Ailin Graef, Second Life' ta yarattı̆̆1 Anshe Chung karakteri ile milyoner olmuştur. Second Life' a 9,95 USD ile başlayan Graef, burada inşaa ettiği yapıları satarak ya da kiralayarak gerçek bir servet edinmiştir. Alışveriş merkezleri, mağaza zincirleri ve sanal borsa yatırımları yaparak elde ettiği servetini ise gerçek paraya dönüştürülebilen Linden doları üzerinden oluşturmuştur (Sweet Moments, 2017). 


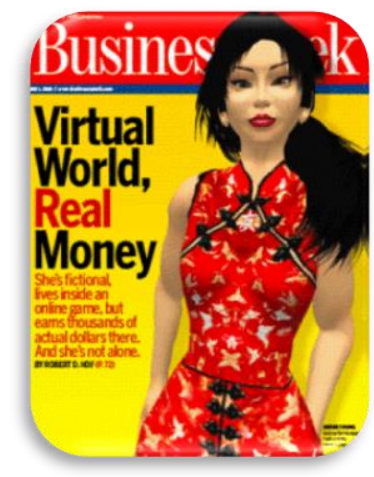

Şekil 3. Second Life'ın ilk milyoneri. Anshe Chung. http://www.sweetmoments.typepad.com/sweet moments/page/4/ ve http://theory.isthereason.com/?p=1410 sayfasından erişilmiştir.

Linden Lab'ın gelir kaynakları arasında çeşitli alanlardaki ticari kuruluşların burada ada satın alması ve ürün tanıtımlarında bulunması da vardır. Örneğin, Mercedes, Toyota, BMW, General Motors, IBM, Sony, Adidas, Nike, Cisco, Dell gibi küresel şirketler, reklâm, ürün tanıtımı, fizibilite çalışmaları, müşteri görüşlerini değerlendirme gibi nedenlerle Second Life’ta bulunmaktadır. Bunun yanı sira, dünyaca tanınan haber ajansı Reuters, CNN gibi haber kuruluşlarının buradaki temsilcilikleri ve muhabirleri Second Life'tan düzenli haber yapmaktadır (Uzun, 2011, s.74). Bunların yanı sıra Second Life'ta ekonomi konusunda danışmanlık yaparak para kazanan kullanıcıların olduğu da bilinmektedir. Türkiye'den de Vestel ve Garanti Emeklilik gibi kuruluşlar Second Life'ta ada ve temsilcilik satın almışlardır. Ayrıca Nisan 2019'da Türkiye (Turkey) kelimesi aratıldığında 415 sonuç elde edilmektedir. Bunlar içerisinde eğlence yerleri, oyun alanları veya özel amaçlar için edinilmiş adalar yer almaktadır.

\section{2. 2. Second Life ve Eğitim}

İnternet tabanlı bilgi çağı olan 21. yüzyılda, bilginin hızlı devinimine koşut olarak eğitim gereksinimleri artmakta ve eğitime yön veren uygulamalar teknoloji ile beraber hızla değişmektedir. $\mathrm{Bu}$ gereksinimlerin karşlanmasında, günümüz öğretim kurumlarının sağladığı geleneksel sınıf olanakları yerini ders yöneticisi ve öğrenenin fiziksel olarak yakın olmasının gerek olmadığı her zaman ve her yerde öğrenme anlayışına dayanan, web ve teknoloji tabanlı derslere ve sanal sınıflara bırakmaktadır. Son yıllarda uzaktan eğitim programlarının içinde yer alan çevrimiçi sanal sınıfların sayısal olarak büyüme hızı artmaktadır (Gunawardena \& McIsaac, Porter'dan aktaran Canbek, 2009).

Eğitim bağlamında da kullanılabilen bilgisayar destekli, çevrimiçi, çok kullanıcılı, üç boyutlu sanal ortamlar "MUVE-Multi-user Virtual Environment" veya "Metaverse" olarak anılmaktadır. Warburton (2009, s.414) eğitimde en fazla kullanılan sanal dünya platformunun Second Life olduğunu söylemektedir. Second Life'ın kuruluşundan bu yana 56 milyondan fazla üyeye sahip olduğu göz önünde bulundurulursa, bu platformun kapasitesinin yüksek olduğu düşünülebilir. Eğitim amacıyla kullanılan diğer çevrimiçi sanal platformlara; OpenSim, There, Twinity, Active Worlds vb. dünyalar örnek gösterilebilir (Can, 2012, s.77).

Dünyanın çeşitli ileri gelen üniversiteleri tanınırlı̆̆1 giderek artan Second Life’’ eğitim programlarına dahil etmektedir. Linden Lab' da eğitimi desteklemekte hatta eğitim ile ilgili organizasyonlara ve çeşitli projelere katılmalarını desteklemek için eğitimcilere farklı olanaklar sunmaktadır. Second Life'ta eğitimciler seminer, konferans ve sempozyumlara katılabileme ve eşzamanlı iletişim kurabilme şansına sahiptir. Bu ortamlarda kullanıcılar avatarları ile kendilerini temsil etmekte, geniş bir coğrafi alana rağmen aynı ortamda bulunabilme deneyimi yaşamaktadırlar. Second Life'ın anlık sesli, yazılı sohbet imkânının olması, video-konferanstan, Adobe Connect gibi programlardan daha etkileşimli olması, eş zamanlı sunu, görsel ve internet bağlantılarının 
kullanılabilmesine imkan tanıması, bu sanal dünyanın popülaritesini artırmaktadır (İstanbul Üniversitesi, 2017).

Second Life bünyesinde sanal kampüs kuran üniversitelere bakıldığında; Arkansas Eyalet Üniversitesi, Ohio Üniversitesi Kampüsü, Saint Leo Üniversitesi Sanal Kampüsü Stanford Üniversitesi Kütüphaneleri, Açık Üniversite, Batı Avustralya Üniversitesi, Rockcliffe Üniversitesi, Edinburgh Üniversitesi, Washington Üniversitesi - Sanal Biyodome, Valdosta Eyalet Üniversitesi'nin yer aldığını görmekteyiz (wiki.secondlife.com, 2019). Türkiye'den ODTÜ ve İstanbul Üniversitesi yer almaktadır. Bu kuruluşlar, Second Life'ta çevrimiçi uygulama, konferans, seminer, sanal eğitim yapabilme özellğinden faydalanmaktadır. MIT, Harvard, Yale, Princeton vb. üniversite, müze ve araştırma merkezlerinin üyeliklerinin bulunduğu The New Media Consortium (NMC) isimli kuruluşun 2006 yllından itibaren eğitim, öğretim, ar-ge kapsamındaki projeleri desteklemek için Second Life' 1 kullandığı bilinmektedir (Uzun, 2011, s.75).

Orta Doğu Teknik Üniversitesi’nde 2004 yilında kurulmuş ve halen aktif olarak çalışmakta olan SIMGE (Sımulations \& Games in Education Research Group), Eğitimde Simülasyon ve Oyun Araştırma Grubunun kuruluş amacı, özellikle eğitimde simülasyonların ve bilgisayar oyunlarının nasıl kullanılabileceğine dair araştırmalar yapmaktır. 2008 yllından itibaren ODTÜ Teknokent bünyesinde Animasyon Teknolojileri ve Oyun Merkezi (ATOM) adı altında bir yapı oluşturulmuş ve yerli oyun geliştiricilerinin yetiştirilmesi hedeflenmiştir (Bayraktutan-Sütçü, 2009, s.340).

Çetin (2013, s. 243), İngilizce aç1lımı Simulation Linked Object Oriented Dynamic Learning Environment olan SLOODLE'ın, simülasyon bağlantılı nesne tabanlı dinamik öğrenme ortamı anlamına geldiğini söylemektedir. Açık kaynak kodlu olan bu proje çok kullanıcılı sanal dünyalardan olan Second Life ile MOODLE (Modular Object Oriented Dynamic Learning Environment) öğrenme yönetim sisteminin özelliklerinin birleştirildiği yeni bir öğrenme ortamı olarak tanımlanmaktadır. Çetin (2013, s. 243), SLOODLE'ın kullanıcılarına büyük bir öğrenme ve öğretme araçları dünyası sunduğunu ifade etmektedir. Tüm bu araçların dünya genelinde binlerce öğrenci ve öğretmenin kullandığı denenmiş ve test edilmiş internet tabanlı öğrenme yönetim sistemlerine ait araçlar olduğu bilinmektedir.

Bezir (2012), San José State Üniversitesi'nin Kütüphane ve Bilgi Bilimleri lisansüstü dersini Second Life sanal ortamını ve geleneksel sınıf ortamını birleştirerek verdiğini söylemektedir. Second Life'ta Harvard Üniversitesi' nin binasında toplantılar düzenlenmekte, sanal kütüphanelerin ve kampüslerin Second Life ortamındaki potansiyelinin araştırıldığı bilinmektedir. Sanal kampüslerde eeğitim ile ders işlenmekte öğrencilerin hem kuramsal hem de uygulama gerektiren dersleri alabilecekleri mekanlar tasarlanmaktadır. Bunun yanı sıra Second Life'ta oluşturulan kütüphane, müze gibi eğitim ortamlarında öğrenciler istedikleri zaman araştırma yapabilmektedir. Ayrıca eğitimciler eş zamanlı olarak yapılan toplantılarda bilgi alış-verişinde bulunabilmektedir.

Canbek (2009), Second Life' taki 3B efektlerin sosyal etkileşimi ve iletişimi artırmakta olduğunu öne sürmektedir. Yine Canbek'e göre; Second Life ortamında öğrenciler avatarları sayesinde öğretmenle, diğer öğrencilerle ve ortamla etkileşime girebilmekte, sosyal, ekonomik ve politik sınırlamaların olmadığı çok kültürlü eğitim ortamlarını deneyimleyebilmektedir.

Gelişen teknoloji ile gündeme gelen sanal gerçeklik ve sanal dünyaların yaratılması uzun süredir bilimkurgu konusu olmaktan çıkmıştır. Teknolojik gelişmeler sayesinde sanal dünyalarda sanal yaşantılar sürdürmek mümkün olduğu gibi artık bu dünyaların eğitim gibi amaçlar için kullanılması ve öğretim yöntemlerinin geliştirilmesi de söz konusudur. Ayrıca "Second Life Educators - SLED" adı altında oluşturulan mail grubu; Second Life’ı eğitim amaçlı kullanan eğitimcilerin oluşturduğu bir gruptur ve dünya çapında birçok eğitimci üyesi bulunmaktadır. Bu grup aracillğı ile Second Life üzerinde araştırma yapan eğitimciler tanışma, eğitim organizasyonları düzenleme ve Second Life'ta karşılaştıkları teknik veya eğitim ile ilgili sorunlarına çözüm bulma gibi etkinlikler yapmaktadır. Bunun yanısıra Second Life Education adı altında forumlar da yer almaktadır. E-posta listeleri ve gruplar ücretsizdir. Eğitim konusunda en iyi uygulamaları, sık karşılaşılan hataları ve hızlı ipuçlarını paylaşan Second Life kullanıcıları ile iletişim kurmak için tercih edilebilecek önemli bağlantılardır. Benzer bloglardan bazıları şunlardır; Arșivler ve Kayıt Yönetimi Sanal 
Merkezi (VCARA), SJSU / SLIS, Sanal Dünyalar Eğitimi Yuvarlak Masası (VWER), Uluslararas1 Eğitimde Teknoloji Derneği (ISTE), Second Life'ta Kar Amac1 Gütmeyenler (NPSL). (wiki.secondlife.com, 2019).

Linden Lab kâr amacı gütmeyen ve vergi statüsüne sahip herhangi bir eğitim kurumuna Second Life'ta eğitimle ilgili etkinlikler yapma olanağı sunmaktadır. Linden Lab, uygun görülen kurum ve kuruluşlara faturalandırma kaydı ile özel bölgelerde $\% 50$ indirim yaparak eğitim sektörünü desteklemektedir. (Second Life, 2019).

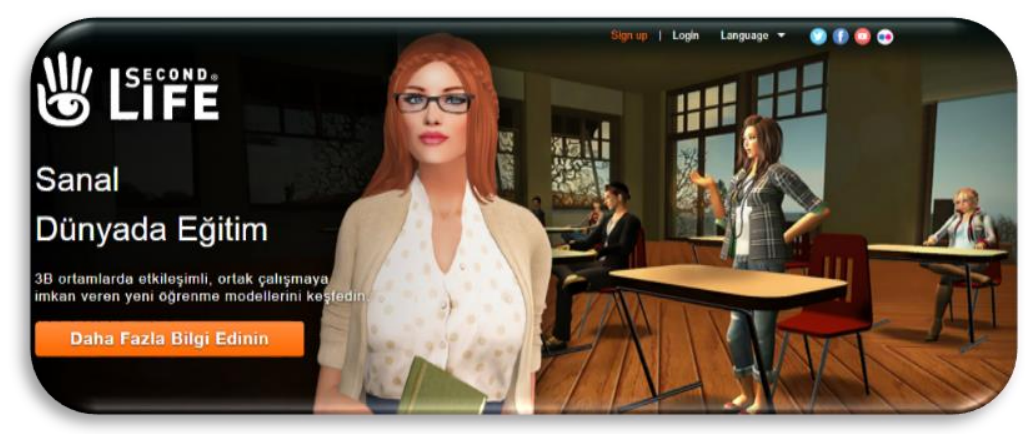

Şekil 4. Eğitim görseli. http://go.secondlife.com/landing/education/tr/?lang=tr 2019

SLED'in yanı sıra Active Worlds eğitimcilerin istekleri doğrultusunda Active Worlds Eğitsel Evrenini hayata geçirmiştir (Active Worlds Educatinal Universe, AWEDU) (Ağca, 2013, s.182).

Second Life, öğrencilerle eğlenceli, interaktif 3B ortamlarda etkileşim kurarak gerçekçi öğretime katkı sağlamaktadır. Sesli ve yazılı sohbet olanaklarını kullanarak gerçek zamanlı ortak çalışmalar yapmaya elverişli ortam hazırlayarak katılımcıların birlikte üretmesi ve birlikte yaratmasını desteklemektedir. Dünyanın her yerinden yüzlerce eğitimciyle tanışma ve küresel topluluklara katılma imkânı sağlamaktadır. Kampüslere erişimi kontrol altına alabilme imkânı sağlayarak eğitimin yapılacağı alanlarda sadece öğrencilerin bulunmasına izin vererek güvenli kampüsler oluşturmaktadır (Second Life.com, 2019).

Second Life'taki Eğitim Yerleri adı altında yayınlanan sayfada; Denizaltı/Akvaryum, Bilim/Genel, Uzay/Astronomi, Kimya/Biyoloji, Klinik/Sağlı/Rehabilitasyon, Çevre, Yaratıcının Kaynakları, Gözlemevi, Jeoloji/Doğa Tarihi, Tele-Hub, Sanat, Tarih /Arkeoloji, Harikalar Diyarı, Mimari, Topluluk, Orman/Doğa, Dünya, Okul/Kendi Kendine Öğrenme, Edebiyat/Kütüphane/Felsefe başlıkları ile gruplandırılmış SLURL'lar yani bu yerlere gidebilmek için gerekli olan adresler yer almaktadır. Second Life'ta bulunan eğitim alanlarına genel bir bakış için docs.google.com linki kullanılabilmektedir (docs.google.com, 2019).

Second Life'ta STEM ve Astronomi, Biyoloji ve Sağlık, Jeoloji ve Doğa tarihi, Sosyal Bilimler ve İnsanlık alanlarında çeşitli müzeler bulunmaktadır (wiki.secondlife.com,_2019).

Bugünün öğrencileri teknolojiyi ve öğrenme materyallerini oldukça yetenekli ve rahat bir şekilde kullanabilmektedir. Bu nedenle eğitimciler öğretme platformlarını, eğitim pedagojisini teknolojiye ve bilgi çağının kültürüne uyarlamalıdır (Wang \& Braman, 2009, s.235).

\section{2. 3. İnşa ve İçerik Oluşturma}

1984 yllinda, Lucasfilm tasarımcilar1 Chip Morningstar ve Randall Farmer, binlerce kullanıcın aynı anda bağlanmasına olanak sağlayacak kapasitede, çevrimiçi ve bilgisayar grafikleri ile daha gelişmiş arayüzlere sahip bir rol oyunu olan Habitat'1 piyasaya sürmüştür. 1986 yapımlı "Habitat" adlı 3B sanal dünya, grafik sanal dünyalar arasında ilk kez, kullanıcı içeriğini dünyaya dâhil etmek için tasarımcı-çıkışlı yapılan bir deneme olarak tanımlanabilir. Avatar kişiselleştirilmesi ve tasarımın yönünün kullanıcılar tarafindan belirlenmesine izin verilmesi gibi olanakları, Metaverse fikrine yaklaşıldığını göstermektedir (Lastowka'dan aktaran Tasa, 2009).

İçerik oluşturma ve özelleştirme araçlarına sahip 3B sanal dünya platformları aşağıdaki tabloda yer almaktadır. 
Ceylan Dadakoğlu, S., \& Aksoy, Ş. (2020). Title in article's language. Journal of Human Sciences, 17(2), 485-512. doi:10.14687/jhs.v17i2.5769

Tablo 1: Ticari/ Açık Kaynak Kodlu 3B Sanal Dünya Platformlarn (Tokel ve Topu, 2017, s.4)

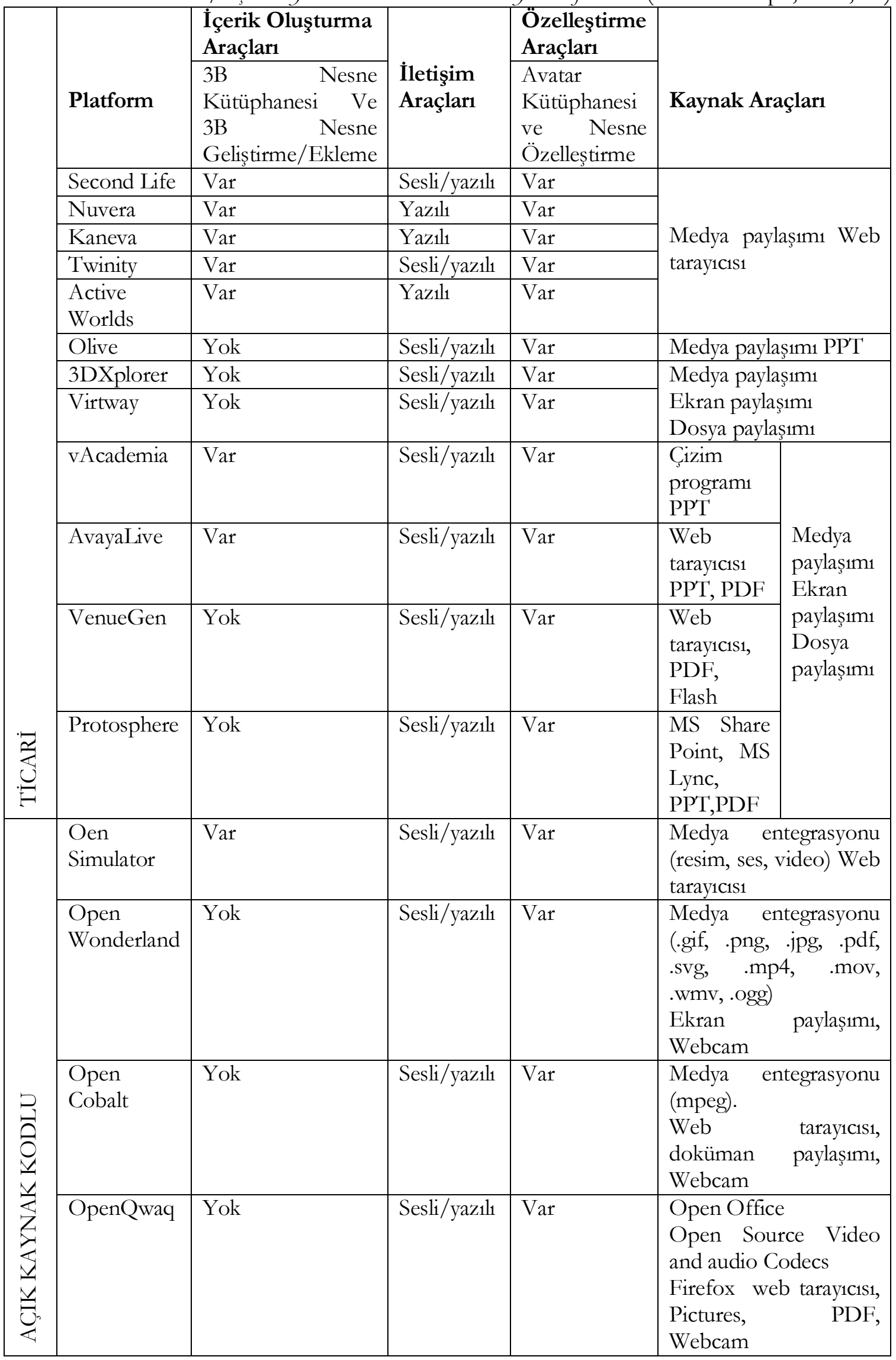


Second Life, çok kullanıcılı bir sanal ortamdır (MUVE-Multi User Virtual Environment), bu sanal dünyanın alt yapısı dışında neredeyse hiç bir tasarım, Linden Lab tarafindan oluşturulmamıştır. Kullanıcılar tarafindan içerikler üç boyutlu tasarım ve kodlama yöntemiyle üretilmektedir.

Second Life'ın kendi üç boyutlu tasarım araciyla küp, küre, silindir gibi temel 3B nesnelerin bir araya getirilmesi, büyütülüp küçültülmesi, oranlarının değiştirilmesi, ahşap ve metal gibi farklı malzemeler arasından seçim yapılması, renk ve doku kaplanması, sşık ve yansıtma özelliklerinin seçilmesi, kesilip oyulabilmesi gibi çok karmaş1k olmayan $3 \mathrm{~B}$ tasarım eylemleri mümkündür. Böylece kıyafetten aksesuara, taşıttan mobilyaya, peyzajdan yollara ve daha da önemlisi binalara kadar her türlü 3B nesne ve ortamı tasarlanabilmektedir. Bu aracın ara yüzü ve kullanım sırasındaki bir ekran görüntüsü, Şekil 5’te görülmektedir:

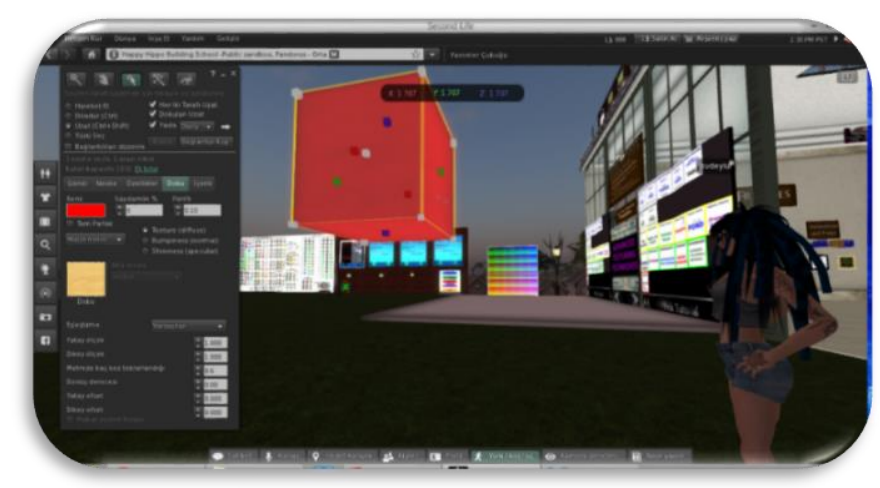

Şekil 5. Second Life tasarım aracı. Ekran alıntısı.

Tasarlanan bu nesneler, istenen yere taşınabilmekte ve çoğaltılabilmektedir. Second Life, $\mathrm{C} /$ Java tarzında deyim ve komutlar kullanılmasına imkan sağlayan bir kodlama dili içermektedir. Bu betik dili Linden Script Language olarak isimlendirilmiştir. Oluşturulan nesnelere kullanıcının tıklamasıyla istenen komut dizisi hem sanal dünya içinde bir nesneye yönelik olarak hem de sanal dünya dışına erişerek bir web sayfasının açılmasını sağlayacak şekilde kullanılabilmektedir (Dinçer, 2008, s.26-27). Örneğin Second Life içerisinde yer alan bütün etkileşimli ve hareketli tasarımlar, parlayan mücevherler, giyilen hareketli kıyafetler vb. hepsi bahsedilen betik diliyle yazılmıştır. Bu betikler, özel diliyle kodlanmış metin tabanlı dosyalar olarak oluşturulmakta ve ilgili nesneye eklenmektedir. Kullanıcıların yarattıkları tasarımlar Second Life'ta sakin adına patentlenmekte, yaratılan nesnelerin telif ve kullanım haklarını sakinler belirleyebilmekte, tasarımlar çoğaltabilmekte, satılabilmekte veya ücretsiz dağıtılabilmektedir. Tasarımlar üzerinde yapılabilecek her türlü değişiklik izin gerektirir ve bu tasarım sahibinin inisiyatifindedir.

Second Life.com. da yer alan bilgi tabanı sekmesinde; Second Life hesap açma, yap1/inşa, avatar, ticaret, envanter, arsa, sosyalleşme, sorun giderme vb. konularla ilgili makaleler yer almaktadir. Bu makaleler bize Second Life ile ilgili temel bilgileri vermektedir (Community Second Life, 2019).

Hızlı bir şekilde Second Life öğrenebilmek (gezinme ve içerik oluşturma yeteneği geliştirilebilme, script kullanabilme vb.) için Second Life Wikinin video eğitimlerinden faydalanma imkânı bulunmaktadır. Video eğitimleri; arşivler, temel bilgiler, kullanıcılar tarafından oluşturulmuş video eğitimleri, içerik oluşturma, Machinima eğitimleri gibi konularda destek sağlayan birçok video ve link barındırmaktadır (wiki.secondlife.com, 2019). 


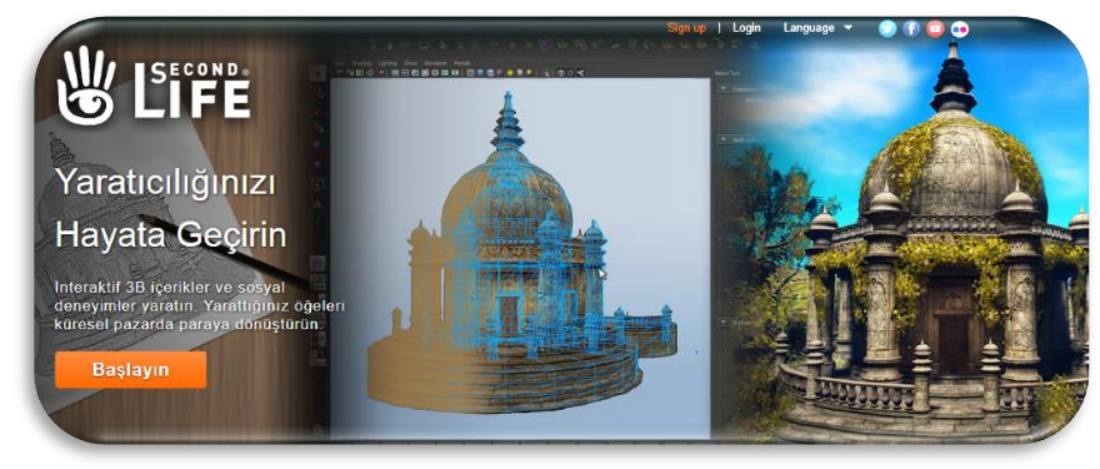

Şekil 6. Second Life, Yaratıcıllı̆̆ınızı hayata geçirin.

http://go.secondlife.com/landing/creator/tr/?lang=tr 27.12.2018

Second Life'ta yer alan her şey; örneğin interaktif 3B nesneler, esssiz deneyimler, dünya çapında oluşturulan topluluklar ve daha fazlası kullanıcılar tarafindan yaratılmaktadır. Second Life yaratıclluğ destekleyen güçlü bir platform olarak tanımlanabilmektedir. Maya ve Blender'da tasarlanan modellerin Second Life'a aktarılmasıyla, Second Life'ın kendi yerleşik araçlarının kullanılmasıyla inşa yapmanın mümkün olması Second Life'1 yaratıcılık konusunda öne çıkarmaktadır. "En İyi İnşa Uygulamaları" adlı Wiki sayfası, yaratıcı ve etkileyici içerikler yaratmaya yardım edebilecek onlarca kaynak sunmaktadır. Yaratılan öğeleri hayata geçirmenin mümkün olduğu bu 3B sanal ortam script denilen kodlama dili ile nesnelere interaktiflik, animasyonlar ve benzersiz davranışlar eklemeye olanak sağlamaktadır. Linden Kodlama Dili (Linden Script Language) kullanıcıların yaratımlarını hayata geçirmelerini sağlamaktadır. Script (LSL) öğreticisi ve script (LSL) portalı Wiki sayfaları, nasıl kodlama yapacağınızı gösteren gerçekçi, interaktif içerikler oluşturmaya yardım edebilecek kaynaklar paylaşmaktadır. Diğer yaratıcılarla bağlantı kurarak topluluklar oluşturmaya olanak sağlayan Second Life, en iyi uygulamaları öğrenme ve daha fazlasını (nesneler, topluluklar, deneyimler vb.) yaratma hakkında birçok bilgiyi paylaşmaya da imkân vermektedir (go.secondlife.com,_2018).

\section{2. 4. Sanat ve Tasarım}

1919'da kurulan Bauhaus, o günün teknolojisini sanatçının eserine uydurmaya çalışmıştır. Sanat teknolojisine (özellikle iletişim araç ve gereçlerine) ve tasarım öğelerine ilgi ile yeni materyallere yönelik maceracı bir tutum Bauhaus'ta bütünleşmiştir (Hurwitz ve Day'dan aktaran Özsoy, 2003). 1970’lerden itibaren, bilgisayarlar, algoritmalar ve işlemsel süreçler sanat yapttlarında merkezi bir bileşen olarak gerçek anlamıyla yer almaya başlamıştır (Tasa, 2009, s.18). Bilgisayar henüz gündelik bir kullanıma girmeden çok önce, sanatçlar tarafindan sanat pratiklerinin yaratıcı bir işbirlikçisi olarak kucaklanmıştır. Bilgisayar donanım ve yazılımının, sanat çalışmalarına doğrudan dâhil edilmesinden önce Roy Ascott ve diğer sanatçılar, sibernetik ile sanat arasında benzerlikler kurup, sanat işlerinde sistemleri, programlanabilirliği ve etkileşimi kullanmışlardır (Shanken’ den aktaran Tasa, 2009).

Sanal gerçeklik yeni bir estetik seçeneği ve sanata yeni bir bakış açısı sunmaktadır (Krueger'den aktaran Akın, 2015). Second Life'taki üç boyutlu tasarım araçları ve betik yazım olanakları (script), Second Life'ın sanatçıların kendilerini ifade ettikleri bir ortam olarak kullanılmasını sağlamıştır. Second Life'ın kendi içerisinde yapılan aramalarda 2019 Nisan ayı verilerine göre "Artist" olarak isimlendirilmiş 3534 kişi, "art gallery" olarak etiketlenmiş 1448 alan, "art museum" olarak etiketlenmiş 123 yer bulunmaktadır.

Kit Galloway ve Sherrie Rabinowitz gibi öncü sanatçılar, birleştirici sanal ortamların olanaklarını erkenden fark edip, uzak ve farklı konumlardan gerçek zamanlı erişilebilen, etkileşimli, kolektif ve ağ üzerinden bağlantılı sanat projelerinde denemeler yapmaya başlamışlardır. 1984 yılında kurdukları Electronic Cafe International, ilk siber cafe olarak tarihe geçmekle kalmamış, 1988-89 yılarında, Active Worlds adlı Metaverse platformunda, üç boyutlu bir ortama da taşınmıştır 
(Tasa, 2009, s.19). Bu ve benzeri sanat projelerinin sanatı belirli ve sadece tek bir coğrafi konumda bulunan fiziksel bir obje olma geleneğinden kurtardığ1 söylenebilmektedir (Shanken, 2003, s.53).

Kullanıcılar tarafindan üretilen içeriğin sanal ortamlarda yer almaya başladığı bu illk örneklerin yanı sıra, çevrimiçi topluluklardaki kullanıcılar, sosyal içeriği ve anlatıları, esasen başından beri tasarımcıların amaçlarının ötesine geçerek kendileri belirleyebilmişlerdir. Sağladığı bu olanaklar sayesinde Sherry Turkle, MUD'lar gibi çevrimiçi ortamlarla, performans sanat1, sokak tiyatrosu ve doğaçlama tiyatro gibi sanatsal biçimler arasında paralellik kurmuş ve MUD’ları ortaklaşmacı (collaborative) yazarlığın yeni türü olarak tanımlamıştır (Turkle'dan aktaran Tasa, 2009, s.6).

Sanat son dönemlerde, çok daha önce tartsşmaya başladığ1 deneyim, etkileşim, süreç ve katılım gibi kavramları, bilgisayar teknolojileri sayesinde çok farklı bir zeminde tartışabilir ve gerçekleştirebilir durumdadır. Sanatın sanat yapıtı, sanatçı ve izleyici arasındaki ilişkilerde çarpıcı bir dönüşüm yaşadığı söylenebilir. Sanat yapıtının sabit, bitmiş ve bağımsız bir nesne olmaktan çıkmış, hareketli, etkileşimli, izleyicinin katılımıyla gerçekleştirilebilen bir sürece ve deneyime dönüşmüş olduğu düşünülmektedir. Sanatçının yapıtın üzerindeki kontrolü ve sorumluluğu gönüllü olarak izleyici ile paylaşan, izleyicinin yaşayacağı etkileşimin çerçevesini tasarlayan birine dönüştüğü görülmektedir. İzleyicinin ise pasif bir gözlemci olmaktan çıkarak, sanat yapıtını tamamlayan, söz sahibi olan, aktif bir konuma geçerek, bütününde bir süreç ve deneyime dönüşen sanat işinin bir parçası haline geldiği söylenebilir. İnternet ortamında sanat, alınıp satılan bir nesneden ortaklaşa üretilen katılımcı bir sürece dönüşmüştür (Tasa, 2009, s.56-57).

Second Life' ta aktif bir sanat ortamı bulunmaktadır. Tasa (2009), bir yanda gerçek hayatta da sanatçı olan Paul Sermon veya DC Spensley gibi sanatçıların, Second Life'ın sanat uygulamalarına getirdiği yeni açılımlarını araştırdıklarını, diğer yanda Second Life'ta "Glyph Graves" olarak tanınan ve gerçek hayatta sanatçı olmayan veya Second Life'ta "Davan Camus" olarak tanınıp gerçek kimliğini açıklamadığı için ne iş yaptı̆̆ını bilemediğimiz sanatçıların var olduğunu belirtmektedir. Second Life sergi açılışlarının yapılabileceği, projelerin uygulanabileceği, etkileşimli işlerin yapılabileceği ve farklı deneyim olanaklarının yaşanabileceği bir ortam sunmaktadır. Bunun yanı sıra Second Life'ta yapılan işlerin alınıp satıldığı, gerçek hayattaki gibi alıcıların evlerinin duvarlarını, salonlarını veya bahçelerini aldıkları sanat eserleriyle süslediği bir sanat pazarının da varllğı bilinmektedir.

Second Life' ta 'DanCoyote Antonelli" olarak tanınan ve ünlü sanatçılardan birisi olan DC Spensley, "hiper-formalizm" olarak tanımladığı bazı soyut çalışmalarında script kullanmaktadır. Aşağıdaki linkten ulaşılabilen örnekte de görüleceği gibi DanCoyote Antonelli interaktif üç boyutlu formlar inşa etmekte ve avatarlarla girilen etkileşim sonucunda formlar yer değiştirerek farklı komposizyonlar oluşturmaktadır.

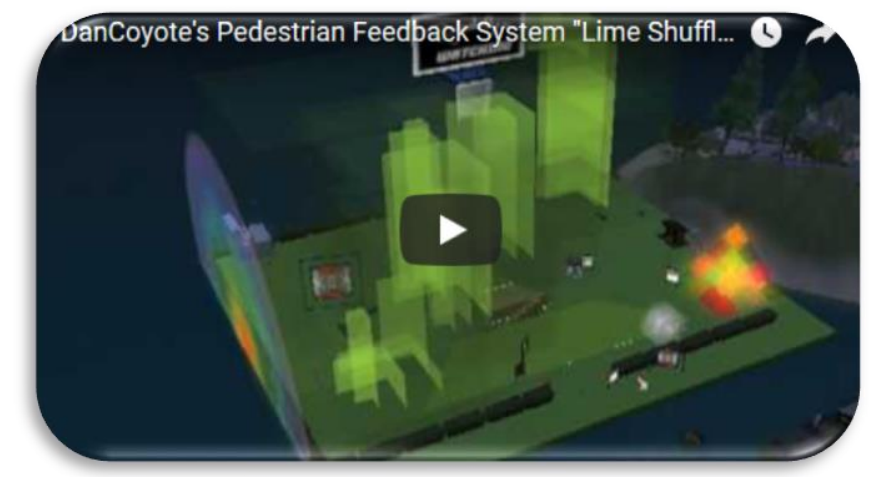

Şekil 7. DC Spensley Studios (2013). Dan Coyote Antonelli http://www.dcspensley.com/art/?portfolio=lime-shuffle sayfasından erişilmiştir. 
Second Life' ta "Glyph Graves" olarak tanınan Davan Camus aslında Avustralya'da genetikçi ve biyologdur. Second Life' ta, genetik algoritmalara uygun olarak geliştirilmiş çok sayıda sanatsal yaşam formları üretmiştir. Yapay organizmaların oluşturulması, yapısı, dokusu ve hareketi arasındaki ilişkinin genel bir estetik araştırması yapmış ve Second Life' ta en popüler ve en çok sergilenen sanal sanatçılardan biri haline gelmiştir. Kendi sözleriyle ifade edilecek olursa (Camus, 2013);

"Grafik, 3B modelleme programlarının, dijital araçların yanısıra Linden betik dilini ve yaratıcılığımı boya-firça gibi özgürce kullanıyorum. Second Life sanatında var olan boyut ve derinlik konularında sürekli merak ve bazen umutsuzluk halindeyim” ifadesini kullanmıstır.

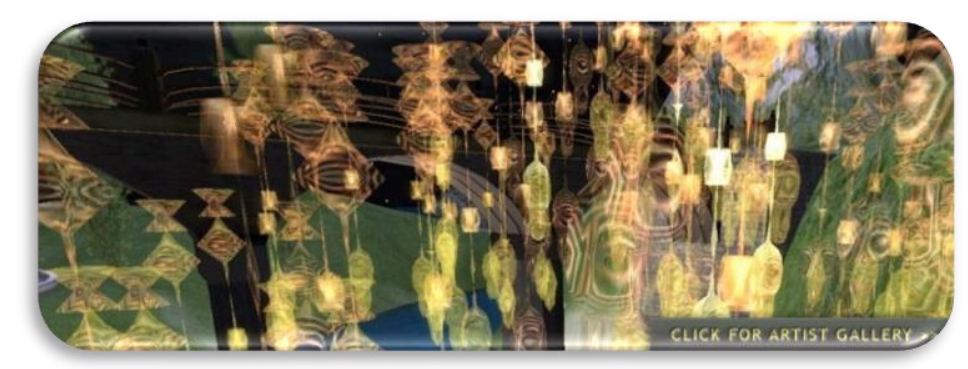

Şekil 8. Glyph Graves. Virtual Art İnitative, Advancing The Art Of The Virtual Worlds (2009). http://www.virtual-art-initiative.org/Virtual Art Initiative/artists/Glyph.html sayfasindan erişilmiştir.

Shanken (2003) “... sanat, mental-kavramsal bir kayma yaratabildiği ölçüde bir değere sahip oldu; sanatçının, sanat yapıtının ve izleyicinin davranışını tersine çeviren ve böylece oluşturdukları sistemin davranışını değiştiren, bir bilinç dönüşümü yaratabildiği sürece..” (s.11) ifadesiyle sanatın doğasını içinde bulunduğu çağa göre yeniden tanımlamaktadır.

Second Life' in ortamı, yüklenebilen dokular, ses klipleri, dünya çapında yapı taşları araçları ve komut dosyalarının kullanılabilmesi, Nebulosus Severine'ın 3B ortamda sanat yapması için önemli ve ikna edici faktörler olarak kendi web sitesinde belirtilmiştir. Severine, teknik alanlardaki diğer sanatçlar ve insanlarla işbirliği yaparak, tüm dünyadaki ziyaretçilerin müzik, durağan görüntü, video, anlatım, etkileşimli nesneler ve tam 3B bakış açısını bir araya getiren yoğun kurulumlarla karşılaştıkları bir sanal sanat oluşturabildiğini ifade etmektedir. Projelerinin çoğu travma, güç ve sosyal temalar üzerinde yoğunlaşmıştır. Ayrılmaz bir parçası olarak tanımladığı son derece özelleştirilmiş, üçüncü bir gözü olan, cinsiyetsiz, insanımsı bir avatar tasarlamıştır. Bunu sürekli gelişen bir stilize portre olarak gördügünü ve onun androjen özelliklerini, toplumsal cinsiyet normlarının sınırlarını aşmak için kullandığını ifade etmektedir. Ayrıca Severine sürekli büyüyen ve sanal gerçeklik sanatının yalnızca güzel sanat ve eğlence uygulamaları için değil aynı zamanda eğitim, topluluk oluşturma ve sosyal değişimi geliştirme potansiyeli olduğuna inandığını da dile getirmektedir (Nebulosus Severine, 2017).

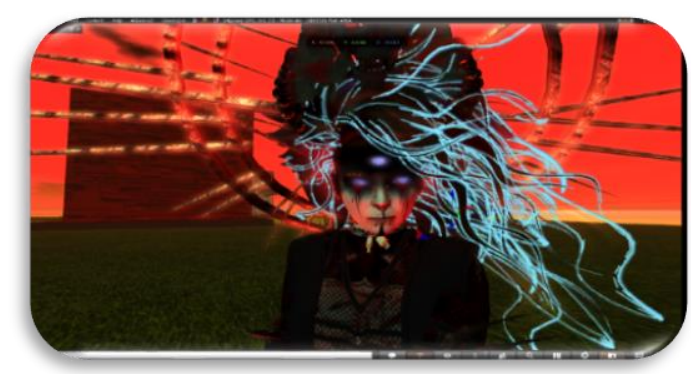

Şekil 9. Nebulosus Severine (2017). Artist http://www.nebulosus-severine.com/new-media.html sayfasindan erişilmiştir. 
Second Life' tan başka gerçekliklere taşınan örnekler, Metaverse'de yerel sanat örnekleri olarak ele alınabilecekken, diğer türlü bir "ithal” eylemi, kopya sanat olarak sınıflandırılmıştır. Bir diğer örnek, Markus Kleine- Vehn / Kristus Yoshiyuki - Second Life Second Art adlı çalışmasıdır. Bu çalışmada yaratılan avatar ve sanat işi, varlıklarını sadece gerçek dünyaya uzatmakla kalmaz, aynı zamanda You'Tube, Flickr ve Blogspot gibi farklı sanal platformlar da yer alırlar (Liao' dan aktaran Tasa, 2009, s.38).

Second Life'taki mimari tasarımla ilgili en çarpıcı olan gelişme, gerçek dünyanın ilgisini de gittikçe daha fazla üzerine çekmesidir. Diğer Second Life mimarları Keystone Bourcard ve Designer Dingson'la beraber New York Times'a konu olan Scope Cleaver, Taschen Yayinevi'nin son Architecture Now serisinde de dünyaca ünlü mimarlar ve projeleri arasinda, Second Life' taki isleriyle ilk kez bir avatar mimar olarak yer almaktadır. Cleaver'in Princeton Üniversitesi'nin Second Life' taki kampüsü için gerçekleştirdiği tasarımlardan birisi Şekil 10'da görülebilir (Tasa, 2009, s. 39).
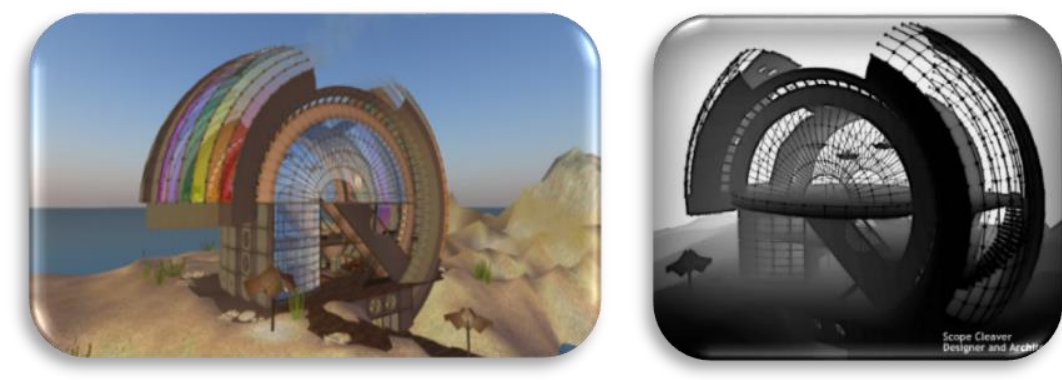

Şekil 10. Scope Claver. Flickr (2008).

https://www.flickr.com/photos/gracemcdunnough/2321423183 sayfasından erişilmiştir.

AngryBeth Shortbread (2019), 2005'ten beri çok kullanıcilı interaktif sanat eserlerini ve eğitim deneyimlerini keşfetmek için ağırlıklı olarak ekran tabanlı sanal dünyaları ve oyun platformlarını kullanmış, animasyon, enstalasyon, topluluk şovları oluşturmuş ve Second Life kullanarak çevrimiçi performanslar yaratmıştır. Garrett Lynch (2019), çevrimiçi sanat, kurulum, performans ve yazma gibi çeşitli şekillerde ağ bağlantılı teknolojilerle çalışan İrlandalı yeni bir medya sanatçısıdır. Çalışmaları sanatsal bağlamda (en açık anlamıyla) ağlarla ilgilenir; sanatsal inisiyasyon, yaratım ve söylem için bir araç, mekan ve bağlam olarak sanatçı, sanat eserleri ve seyirci arasındaki boşluklar. Son zamanlarda canlı performansta en aktif olan Garrett'in ağ bağlantılı uygulamaları çevrimiçi sanat, kurulum, performans ve yazmayı kapsar. Gleman Jun (2019), Second Life'ta renklerin, 1şıkların ve saydamlıkların dinamik etkilerinde, kendisini sürekli değişen ve dönüştüren yaratıcılığını ifade eder. Second Life, Machinima ile çekim yapmak için popüler bir mecradır. Second Life'da aktif olan ve yaratıcı etkinliklere katılan birçok Machinima ve sahne sanatları grubu yer almaktadır. Second Life'ta birçok sanat dalında çeşitli pratikler sergilenmektedir.

Second Life'ta canlı müzik performansları mikrofonlar, enstrümanlar veya diğer ses kaynakları aracıllŏgyla bilgisayar ses arabirimlerine girerek ses sunucularına canlı olarak aktarılabilmektedir. Çeşitli yayın yazılımları yardımıyla ses örneklerinin yüklendiği Second Life'ta birçok canlı müzik performansı yapılmaktadır. Bunun yanısıra Second Life'ta birçok tiyatro gösterisi sunulmaktadır. Second Life'ta sanal dans yapılmaktadır. Örneğin Ballet Pixelle (2019) bale sanat formunu yeni ve mevcut izleyicilere taşımak için teknolojiyi kullanmıştır. Türünün ilk ve tek örneği olan şirket, Second Life sanal dünyasında performans sergilemiştir. Şirket, sanal gerçekliğin benzersiz yönlerini yaratıcı bir şekilde kullanmış (örneğin insandan hayvana veya dönüşme), sanal dünyada performans sergileyerek coğrafi sınırları ve zaman dilimlerini ortadan kaldırmıştır.

Second Life Sanat, Second Life' taki en popüler sanat gruplarından biridir. Amacı, sanal dünyalardaki sanatın, gerçek yaşamdaki görsel sanatlarla aynı seviyede olduğunu göstermektir. Windlight Magazine, Second Life Newser ve Second Life Enquirer gibi Second Life Sanatını tanıtmaya çalışan birçok Second Life yayını bulunmaktadır (Wikipedia,2019). 
Son 50 yıldır elektronik ve dijital teknolojiler yeni yaratım tekniklerini oldukça hızlı bir şekilde beraberinde getirmeye devam etmektedir. Çağdaş sanat gelecekte hala insan var olacaksa teknolojiyi gelişimin bir parçası olarak benimseyerek değişmeye, çeşitlenmeye devam edecektir. Gelecekteki sanat için A. Michael Noll'un söylemi ile "Gerçekten ihtiyacımız olan şey yeni bir sanatç1- bilgisayar bilimcisi türüdür” (Avcı Tuğal,2018, s. 254-258).

\section{2. 5. Second Life' ta Sanat eğitimi}

Eğitim kapsamında Second Life, yapıcı öğrenme, sosyalleşme, araştırma ve keşfetme için çok zengin bir ortam sağlamaktadır. Böyle bir sanal ortam öğrenenlerin teknolojik araçları kullanma, üç boyutlu tasarım yapabilme ve bu ortama yenilikler getirme beceri ve stratejilerini göstermelerine olanak sağlamaktadır. Bu sanal ortam özellikle uzaktan öğrenenler için oldukça büyük bir potansiyel taşımaktadır (Burgess, Slate, Rojas-LeBouef ve LaPrairie, 2010, s.84).

Akademisyenler sanal dünyaların ilköğretimden yükseköğretime kadar eğitimin her kademesinde nasıl kullanılabileceğini araştırmaktadır. Örneğin 2001'de Bailey ve Moar, sanal dünyaların ilkokul seviyesinde avatarların ve sanal dünyaların yaratılmasının eğitim olanaklarını daha iyiye götürdüğünü ortaya koymuştur. 2005 yllında Sakatani ortaokul öğrencilerinin sanal dünyaları nasıl tasarladığ1 ve geliştirdiklerinin bir örneği olarak Harmony Quest projesini uygulamıştır. Sakatani sanal gerçekliğin eğitsel yönlerinin (etkileşim, uygulama, bakış açısı vb.) ve sanat eğitiminde ileri düzey etkileşimli teknolojilerin kullanılmasının, disiplinler arası sanat temelli müfredatı destekleyebileceğini ifade etmektedir. 2010'da Gill, bir lisede 3B modelleme ve animasyon yazılımını kullanan bir vaka çalışması yapmıştır. Öğrencilere görsel kültür bağlamında öğrenci merkezli ve yapılandırmacı deneyimler sağlayarak, üç boyutlu modelleme ve animasyon eğitimi başarısında bu ortamların potansiyelinin fazla olduğu sonucuna varmıştır (Akt. Han, 2016, s.72)

İlköğretim sanat eğitimi kavramlarının (drama, dans, medya, müzik, görsel sanatlar) gelişimini desteklemek adına Zagami (2007) Griffith Üniversitesi (Avustralya) için geliştirilmiş bir Second Life ortamını kullanarak, Second Life'ın sanal çevrede kullanımını araştırmıştır.

Akademisyenlerin çoğu, yükseköğretimde K-12 eğitiminden çok sanal dünya uygulamalarını araştırmıştır. Lu (2010) 2008 ylında başladığı araştırma projesi Art Café ile sanal dünyaların, katılımcıları sanata açılmaları ve özgürce tartışmaları için motive ettiğini ifade etmiştir. Lu ayrıca sanal dünyaların, anında geribildirim ve işbirliği ile aktif sanat öğrenimi için hizmet edebileceğini de belirtmiştir.

Bir diğer yükseköğretim araştırmasında Jacka (2010) Second Life sanal ortamını Southern Cross Üniversitesi'nde okuyan Görsel Sanatlar Eğitimi öğrencilerinin eğitiminde pedagojik bir araç olarak denemiştir. "Second Life Sanal Dünyasında Görsel Sanatlar Eğitimi: Sanal Sanat" isimli araştırmada, Second Life ortamında öğrenciler, 2 ve 3 boyutlu sanat eserleri yaratmış, bir sergi alanı tasarlamış, sanat sitelerini ziyaret etmiştir. Bu örnek olay/durum çalısması, geleneksel yöntemler ile Second Life yöntemini karşılaştırmıştır. Görsel sanatlar öğretmen eğitiminde sanal ortamlar ve eğitim ile ilgili hizmet içi eğitimin gerekliliği sonucuna ulaşılmıştır.

Sanal dünyalar, teknoloji ve sanat eğitimi ilgili konuları tartışan ve çok sayıda fasıl içeren ilk yayın, Sweeny tarafından 2010'da düzenlenen 'Etkileşimler/Kesişimler: Dijital görsel kültürde sanat eğitimi” isimli kitaptır. 2014'te Mary Stokrocki, “Sanal dünyada keşif” isimli, sanal dünya ve sanat eğitimine ayrılmış ilk kitabı yazmıştır (Han, 2016, s.66).

Sanal sınıf ortamında, öğrencilerin üç boyutlu dünyaları işbirlikli mimari tasarımda kullanabilmeleri için gerekli bilgi ve beceriyi edinebilmeleri amaciyla yapılan araştırmada Gül (2011), eğitimde geleneksel mimari atölye kavramına ek olarak üç boyutlu sanal dünyaların kullanılabilirliğini deneyimlenmeyi hedeflemiştir.

Bir başka çalışmada Taylor ve Parsons (2011), "21. Yüzyll Becerileri için Dijital Hikâye Anlatmada Sanal Öğrenme Ortamları”nı incelemiştir. Yeni sanal öğrenme ortamlarının, dijital kaynak, araç ve uygulamaların kullanıldığı daha fazla alan ve uygulama içerdiği araştırmacılar tarafından ifade edilmiştir. Araştırma, öğrencilerin gelecekteki çalısma hayatlarında ihtiyaç duydukları 21. yüzyıl becerilerini ve yetkinliklerini öğrenmek için dijital hikâye anlatımının nasıl sanal öğrenme ortamları oluşturabileceğini tanıtmaktadır. Çalışma, üç ülkede öğretmenlerin ve 
öğrencilerin dijital öykü anlatımına ve öğrencilerin ne öğrendiklerini düşündüklerine değer verdiklerini anlatmaktadır. Deneyimleri, 1)öğrenen odaklı bilgi ve becerilerin oluşturulması, 2)işbirliği, 3)ağ oluşturma ve 4)dijital okuryazarlık gibi süreçlerin veya araçların kategorilerini belirleyen küresel paylaşım pedagojisinin bir kavramlaştırması kullanılarak çözümlenmiştir. Araştırma, öğrencilerin dijital hikâyelerini oluştururken yaşadıkları deneyimleri ve öğrenmeyi nasıl yaptıklarını açıklamaktadır. En önemli bulgular öğrencilerin hikâyelerini yaratmalarının keyifli olması ve çalışmalarının oldukça yoğun bir tempo içerisinde tamamlanmasıdır. Sonuç olarak öğrenciler dijital hikâyelerini oluştururken 21. yüzyllın birçok becerisini öğrenmektedirler.

Stokrocki (2011), sanat eğitiminin bu yeni dijital kültür ortamındaki rolünü; sanat öğretmenleri ve okul sistemlerinin dijital öğrenme ile gerçek yaşamda öğrenme arasında uygulanabilir bir dengeyi kurabilmeleri, sanat eğitimi ve öğretiminin değerlendirilmesi konusunda öğretmenlere yardımc1 olabileceği, sanat eğitiminin öğrencilerin dijital kültüre daha eleştirel yaklaşmalarına yardımcı olacağı görüşleriyle açıklamaktadır. Stokrocki (2011), sanal dünyalarda, sanat öğretmenlerinin ve öğrencilerin üç boyutlu öğrenmeyi kavrayabilmeleri, bu üç boyutlu deneyimin görsel, işitsel, sözlü ve şimdi de kinestetik alanı kapsadığını ifade etmekte ve bu platformda sanat öğretmenleri ile sanat öğrencilerinin birlikte öğrenmesi gerektiğini söylemektedir. Ayrıca sanat eğitimcileri ve öğrencilerin öğrenmeyi dijital ortamda gerçekleştirmeleri ve planlamaları dolayısıyla bu planlarını gerçek dünyadaki olasılıklara dönüştürmelerini sağladığı için dijital öğretim teknolojilerinin, dijital dünyaların potansiyel aralığının sonsuz olacağını belirtmektedir (Kellner \& Share, 2005'dan aktaran Stokrocki,2011).

John Kirriemuir, bir oyun-içinde-öğrenen araştırmacı ve aynı zamanda Virtual World Watch'ın yazarıdır. 2006 yılı yaz başında ve 2012 yılının ilkbaharında İngiltere'de yükseköğrenimde sanal dünyanın kullanımını özetleyen bir dizi rapor yazmıştır. Kirriemuir araştırmalarında "Sanal dünyalar eğitim için faydalı olan şeylere katkı sağlıyor mu?" sorusuna cevap aramış ve kesin bir "Evet" cevabını aldığını belirtmiştir (Kuksa \& Childs, 2014, s. 102).

2014 yllinda Carpenter ve Lin Second Life'ın sanal dünyasında görsel kültür üzerine lisans ve lisansüstü dersleri vermiştir. Carpenter ve Lin, deneyimlerinden öğretmen ve öğrencileri meşgul etmek, çoklu perspektiflere dikkat etmek, bir avatar aracilığıla bir performans sergilemek ve aksi halde yapılmayan şeyleri denemek için uğraşmak gerektiğini öne sürmüştür. (Han,2016, s.73)

Janet ve Miles, sanat ve tasarım tarihi ve kuramlar, nesneler, eserler, felsefeler, kişilikler ve eleştirel söylemler etrafinda tasarlanmış çevrimiçi çok kullanıcılı bir sanal ortam olan ARTEMIS'in (Art Educational Multiplayer Interactive Space) kullanımını araştırmışlardır. Janet ve Miles, yeni nesil için sanat ve tasarım eğitiminin öğretim pedagojisinin ve öğrenme ihtiyaçlarının yeniden incelenmesi gerektiğini belirtmiştir (Han, 2016, s. 69).

Second Life'ın Cerulean Gallerisinin eş yöneticileri Julian \& G. Crooks kendi sergileri "Kasırga \& Liken" için bir "Machinima" sunmuşlar ve konferans sırasında konferans katılımcılarını ve tüm dünyayı kendi Second Life galeri alanlarının açllş̧ resepsiyonuna davet etmişlerdir. Küratör Julian \& G. Crooks, aynı zamanda Second Life sergi tasarım ve kurulum sorumlusu olarak, Second Life galerisinde sanatçılarla çok çeşitli eserler üzerinde fikir alış verişinde bulunmuştur (Julian ve Crooks'dan aktaran Bülbül, 2016).

K-12 ve daha yüksek eğitim ortamlarında görsel kültür öğretimi için ve uzaktan eğitimin bir parçası olarak sanal dünyaların kullanılabileceğini iddia eden Han (2016), sanal dünyaların "3 boyutlu sanat, yerleştirme sanatı, interaktif sanat ve animasyon öğretmek için harika bir yer olabileceğini" öne sürmektedir. Taylor, Ballengee-Morris\&Charpenter (2010) Second Life'in sanal dünyasını, avatarların kullanımını ve Second Life ile sanat eğitimi arasındaki ilişkiyi incelemiştir. Sanal dünyaların, "etkileşimli, işbirlikçi, araştırmaya dayalı, yapıcı, bağlı, disiplinler arası ve ilgisiz provokatif" sanat eğitimini teşvik ettiğini savunmaktadır. Lu 2014'te, sanat eğitiminde sanal dünyalar hakkındaki literatürü gözden geçirerek, "3B sanal dünyalar çağdaş bir sanat medyası, yenilikçi bir öğrenme arac1, sanal bir sanat/öğrenim ortamı, bir yaratma ve sergi alanı ve bir sanal topluluk görevi görebilirler. " sonucuna varmaktadır. Bütün bu araştırmacılar, sınırsız imkânlar nedeniyle sanal dünyaların sanat eğitiminde önemli bir yere sahip olduğunu ifade etmiştir (Han, 2016, s.66-67). 
Sanat ve tasarım eğitiminde sanal ortamın yaratıcıllğga etkisi (Second Life Örneği) konulu araştırma ile Ceylan Dadakoğlu (2018) sanal ortamlarda yapılan 3B tasarım uygulamalarının yaratıcllık üzerinde olumu etki edebileceği sonucuna varmıştır.

Second Life sanal ortamında sanat eğitimi ile ilgili yapılan sempozyumlar, haftalık eğitim toplantıları, sanatsal aktiviteler, tasarıma dayalı etkinlikler, görsel sanatlar eğitiminin ayrılmaz bir parçası olan galeri ve müze ziyaretleri gibi çok sayıda etkinlik ve araştırma olduğu bilinmektedir.

Yukarıda alanyazın çerçevesinde sanat eğitiminde Second Life'ın kullanımına yönelik araştırmalara dikkat edildiğinde üç boyutlu düşünme/modelleme, işbirlikçi öğrenme, sanal bir sanat ögrretim ortamı, sanal bir sanat eğitimi pedagojisi, dijital öğretim teknolojileri/dijital araç ve ortamları kullanabilme, 21. yy becerileri, yaratıcilık, sanal ortamlarda sanat ve tasarım yapabilme gibi ifadelerin ön plana çıktığı görülmektedir. Bu ifadeler sanat eğitimi ve sanal dünyalar arasındaki ilişkiyi ortaya koyabilmektedir.

\section{Tartışma ve Sonuç ve Öneriler}

Bulgularda da görüldüğü gibi son yıllarda teknolojinin eğitim içerisindeki kullanımı hızla artmaktadır. Teknolojinin gelişmesiyle beraber eğitim ortamlarının, eğitimdeki yöntem ve uygulamaların hızlı değişimi ve yeniden yapılandırılması kaçınılmaz olarak değerlendirilmektedir. Bilgisayar teknolojisindeki gelişmelerin önemli sonuçlarından biri olan çevrimiçi, üç boyutlu sanal ortamlar kullanım olanaklarına göre birçok alanda tercih edilebilmektedir. Dolayısıyla eğitim ortamlarına da sanal dünyalar dahil edilmekte ve sanal dünyaların eğitim bağlamında kullanılabilirliği sıklıkla araştırılmaktadır.

Jacka’ya (2010) göre; bir öğretme ve öğrenme ortamı olarak sanal dünyalar oldukça kapsamlıdır ve bu durum şu anda pek çok öğrenci için motive edici olabilecek bir deneyim olarak görülmektedir. Ayrıca sanal dünyalar, aktif öğrenme, işbirlikli öğrenme ve problem çözme gibi karmaşı öğretim stratejilerinin daha fazla kullanılması için büyük bir potansiyele sahiptir. İlgi çekici öğrenme ortamlarının temel özellikleri içerisinde zengin teknolojik olanakların yer aldığ1 bilinmektedir. Taylor ve Parsons (2011), başarılı öğrenci için ilgi çekici sınıfların beş özelliği olduğunu öne sürmüştür. Bunlar arasında teknoloji açısından zengin öğrenme ortamları, sadece bilgisayarlar değil bilimsel donanım, multimedya kaynakları, endüstriyel teknoloji ve taşınabilir iletişim teknolojisinin çeşitli biçimleri de dâhil olmak üzere her türlü teknolojinin kullanılması yer almaktadır.

Alanyazında görüldüğü üzere günümüzde gelişen teknoloji, sanal dünyaların eğitim amaçlı kullanılmasını ve sanal eğitim ortamlarının geliştirilmesini mümkün kılmaktadır. Örneğin sesli/yazılı sohbet, eş zamanlı sunu vb. teknik olanakların bulunduğu Second Life sanal dünyası alternatif bir eğitim ortamı olarak değerlendirilebilmektedir. Birçok üniversite Second Life'1 eğitim programları içerisine almıştır. Second Life kullanıcılarına, çok kültürlü eğitim ortamlarına erişebilme, interaktif 3B ortamlarda gerçekçi öğretime katkıda bulunma, katılımcıların birlikte üretmesi ve birlikte yaratmasını teşvik etme, küresel topluluklara katılma imkânı sunma, kampüslere, sanat galerilerine ve çeşitli müzelere erişimi sağlama gibi konularda firsatlar sunmaktadır.

Son yıllarda eğitim ortamlarının reel ortamlardan uzaktan eğitime yani sanal dünyalara taşınacağı görüşü ön plandadır. Fiziksel sınırları ortadan kaldıran çağımız teknolojisi sayesinde gelecekteki uzaktan eğitim sistemlerinin mevcut okul sisteminin yerine geçmesi beklenmektedir (Çoruh, 2011, s. 73-74). Buna bağlı olarak 3B sanal ortamlarda ve Second Life'ta eğitimin fayda ve gerekliliği üzerine birçok araştırma yapılmış, sonuçlar bu ortamların alternatif eğitim ortamları olarak kullanılabileceği ve eğitimde birçok fayda sağlayacağı yönünde kendini göstermiştir.

Bir başka bulguda da görüldüğü gibi Second Life'ın sadece alt yapısı Linden Lab tarafindan oluşturulmuştur. Alt yap1 dişındaki tüm içerikler üç boyutlu tasarım ve kodlama yöntemiyle kullanıcılar tarafindan üretilmektedir.Second Life'ın 3B tasarım araçları aracıllğıyla kullanıcıların yapmak istediği her şey tasarlanabilmektedir.Dolayısıyla Second Life sakinlerinin yaratıcılıklarını geliştirebilecek bir sanal dünya olarak yorumlanabilmektedir. Bu durumun öğrenciler için bir motivasyon kaynağı olarak değerlendirilebileceği düşünülmektedir. 
Coffman ve Klinger'a (2008) göre; bu yüzyılda eğitim, iletişim, özerklik ve öğrencilerin kendi öğrenmeleri üzerindeki hakimiyetlerinin, artırılmış yenilik ve yaratıcllı üzerine odaklanması gerekmektedir. Teknolojik ortamlarda, öğrenciler hem içerik üreticisi hem de tüketicisidir. Bu nedenle, dijital ortamlarda çalışma becerilerine ihtiyaç duymaktadırlar. Buldukları ve yarattıkları bilgiyi eleştirel olarak değerlendirmeli ve doğrulamalıdırlar. Her disiplindeki yetişkin topluluklar tarafından kurulan söylem ve tartışmacı normlara karşı sorumlu olmalıdırlar. Ayrıca sosyal medyayı yaratma ve sosyal medyada tartışma becerileri ve bu ortamlarda etik davranışı geliştirme yeteneğini de kazanmalar1 gerekmektedir (Niemi vd, 2014, s. 660).

Second Life sanal dünyasının kolay 3B tasarıma izin vermesi sonucunda üç boyutlu düşünebilme, yaratıcıllğı ön plana çıkarmasıyla benzersiz görünen modeller üretmeye olanak sağladığı bilinmektedir. Mevcut sanal dünyaların çoğunun eğitim için özel olarak geliştirilmediği ve öğrenciler tarafından kolaylıkla kullanılamadığı için eğitim çevresi dikkatle tasarlanmalıdır. 3B sanal dünya, bireylere uygulayarak ve deney yaparak öğrenmeye izin vermektedir (Gül, Gu ve Williams, 2007, s.44-47).

Second Life, bilgisayar teknolojilerinin gelişmişlik düzeyini gösteren 3B bir uygulamadır. Second Life'ta kullanıcılar avatarlar aracilığıyla iletişim kurabilmekte, 3B modelleme araçlarını kullanarak alternatif bir dünya tasarlayabilmektedir. Second Life’ta sosyal, kültürel ve eğlence amaçlı aktiviteler yapılabilmekte ve kullanıcılar gerçek dünyadaki gibi etkileşime girebilmektedir.

Ayrıca sanal öğrenme ortamları kullanıcılar/öğrenciler tarafindan yaratılan içerik ve nesneler yoluyla oluşturulabilir, değiştirilebilir ve geliştirilebilirler. Öğrenciler senaryolar oluşturup işbirliği içinde öğrenebilirler, geçici olarak bir astronom, kimyager veya mühendisin sorumluluklarını gerçek dünyadaki sonuçları olmadan deneyimleyebilirler. Öğrenciler kendi ortamlarını tasarlayıp inşa edebilir, kendi yaratımlarına sahip olabilir ve kendi bilgilerini özgürce üretebilirler. Böylece öğrenciler hem yarattıkları nesne ve içerikle hem de başka öğrencilerle/kullanıcılarla etkileşim kurabilirler. $\mathrm{Bu}$ bağlamda, öğrencilerin öğrenme sürecinde daha etkin ve bağımsız olduğu düşünülebilir (Kluge \& Riley, 2008, s.130).

Öte yandan sanal ortamların yeni bir sanatsal bakış açısını da beraberinde getirdiği bulgularda görülmektedir. Second Life, reel yaşamda var olan her şeyi sayısallaştırarak yeniden yaratmıştır. Bu yeniden yaratımın içinde sanat eseri ve sanatçlar da yer almaktadır. Sanatçlar ve eserleri sayısallaştırıldığında da kabul görmüş ve sanal ortamlarda sanatsal çalışmalar ve sergilemeler yapılmıştır (Şahin,2010, s.129-130). Second Life'nn keşfedilen olanakları, birleştirici gücü, etkileşimli görüntülere izin veren yapısı birçok sanat pratiğinin bu ortamda uygulanmasını sağlamıştır. Performans sanat1, sokak tiyatrosu ve doğaçlama tiyatro, dans, müzik, heykel, resim, mimari tasarım gibi alanların Second Life'ta birçok kez sergilendiği bilinmekte ve sanatsal yaratıcılık açısından bu sanal ortam değerlendirilebilmektedir.

Günümüzde birçok araştırmac1 sanal dünyaların eğitimin her kademesinde nasıl kullanılabileceğini araştırmaktadır. Bulgularda görüldüğü üzere Second Life sanal dünyası kullanılarak yapılan araştırmalar sonucunda, bu sanal ortamın, işbirlikli öğrenme, yapıcı öğrenme, araştırma ve keşfetme, 3B tasarım yapabilme, yaratıcıllğ̆ keşfetme gibi konular için zengin bir ortam sunmakta olduğu görülmüsstür. Bu bağlamda teknolojinin gelişmesi ve sanal dünyaların eğitimde kullanımıla beraber sanat derslerinde elde edilebilecek kazanımlara değinmek yerinde olacaktır. Bu kazanımlar;

- Öğrencilerin içinde bulundukları dijital dünyayı anlama, yorumlama, sanat ve görsel kültür dünyalarında var olabilme (yaşam becerileri) becerileri kazanabilmeleri (Wilson,2011),

- Sanal dünyaların öğrenmeyi etkili kılması ve ilgi çekici hale getirmesi sonucunda, hayal gücünün öğrencilerin problem çözme yetilerini geliştirmesi, yüksek düzeyde etkileşimli öğrenme deneyimleri sağlaması. Öğrencilerin beyin firtınası yapabilmeleri, bilgiyi yapılandırabilmeleri ve farklı kaynaklardan elde edilen bilgileri sentezleyebilmeleri (Doğan vd, 2011),

- Yeni teknolojiler sayesinde ortalama kişilerin arşiv yapabilmesi, içeriğe yorum ekleyebilmesi ve içeriği değiştirebilmesi (Kellner \& Share, 2005'dan aktaran Stokrocki, 2011), 
- Sanal dünyaların operasyonel, kültürel ve teknolojik okuryazarllğ1 gerektirmesi ve dolaysıyla geliştirmesi (Guzzetti, Elliott, \& Welsch'dan aktaran Stokrocki, 2011). Öğrencilerin dijital talimatları okuyabilmeleri ve dijital tasarımlarını (kendi web sayfalarını, dijital dergilerini vb) yaratabilmeleri (Thomas, 2007'dan aktaran Stokrocki, 2011),

- Sanal dünyalarda, sanat öğretmenlerinin ve öğrencilerin üç boyutlu öğrenme hesaplarını görmeleri ve bu deneyimin görsel, işitsel, sözlü ve kinestetik alanı kapsaması (Stokrocki, 2011, s.5),

- Sanal dünyaların öğrencilerin yaratıcılıklarını keşfedebilecekleri ilgi çekici bir ortam olabilmesi (Han, 2017, s.20). Second Life'nn kendi yapısının özgür ve yaratıcı olabilmesi, Second Life sanal ortamının yaratıcılığı olumlu yönde etkileyebilmesi (Ceylan Dadakoğlu, 2018, s.286),

- Sanal dünyaların, dünya çapında iletişim kurma firsatları sunmasından dolayı iletişim kurma becerilerinin gelişmesi, birçok sanal platformda sanat yapma ve sanatı sergileme olanakları sunması (Stokrocki, 2011) şeklinde sıralanabilir.

Çağımızda teknolojinin hızlı gelişimine paralel olarak bireylerin ihtiyaç duyduğu becerilerin değiştiği görülmektedir. 21. yy eğitimden teknoloji ile uyumlu, girişimci, eleştirel düşünebilen, araştıran, sorgulayan, bilgiye ulaşabilen, grup çalışmasına yatkın bireyler beklemektedir. Dolayisiyla eğitim sistemlerinin, yöntemlerinin, araç gereçlerinin yaşanılan çağa ve teknoloji gibi değişkenlere bağlı olarak dönüştürülmesi kaçınılmazdır. Dünya çapında sanat eğitimi yöntemlerine bakıldığında teknolojinin eğitime dâhil edildiği görülmektedir. Sonuç olarak geleneksel sanat eğitimi anlayış1 içerisinde teknolojinin, çeşitli bilgisayar uygulamalarının, 3B sanal dünyaların, sanal gerçeklik (VR) ve artırılmış gerçeklik (AR) uygulamalarının kullanılması ve tüm bunların etkinliklere dâhil edilmesinin günümüz sanat eğitimi kazanımları açısından önemli olduğu düşünülmektedir. $\mathrm{Bu}$ nedenle Second Life sanal dünyasının ve diğer 3B sanal ortam, araç ve uygulamaların sanat eğitimine dâhil edilme biçimlerinin sorgulanması gerekli görülmektedir.

Günümüz gençleri "dijital yerli” olarak adlandırıldıklarından dijital ortamlardan bağımsız düşünülememekte ve birçok öğrenme biçimi için dijital ortamları tercih edilebilmektedir. Teknolojiye bağlı olarak sanat eğitimi içerisinde sanal uygulamalara yer verilebileceği, Second Life'ın, sanat ve tasarım eğitimcileri için bir eğitim ortamı olarak değerlendirilebileceği önerilmektedir. 21. yy becerileri göz önüne alındığında eğitim kurumlarında sanal dünyaların ve uygulamaların hem genel eğitim hem de sanat eğitimi içerisine entegre edilebilir ve uygulanabilir olduğu düşünülmektedir. Bunun için sanal dünyaları müfredata dâhil etme çalışmaları, öğretmen eğitimleri ve sanal dünyalarda yapılabilecek uygulama örneklerine gereksinim duyulmaktadır.

\section{Kaynakça}

Acaroğlu, K. (2010). Etkileşimli sanal dünyanm (Second Life) modelleme tekniklerini kullanarak sanal sanat galerisi oluşturulması. (Yüksek lisans tezi). https://tez.yok.gov.tr sayfasından erişilmiştir.

A ğca, R., K. (2013). Sanal dünyalar ve oyunlarda sosyal etkileşimler. Ocak, M., A. (Ed.). Ë̆gitsel dijital oyunlar, kuram, tasarm ve uygulama içinde (s.180-195). Ankara: Pegem A.

Akın, C. (2015). Dijital sanatlarda etkilesimsellik: Türkiye'de etkileşimsel dijital sanatlarn konumu üzerine bir inceleme. (Doktora tezi). https:/ / tez.yok.gov.tr sayfasından erişilmiştir.

Arizona State University (2019). Mary Stokrocki’nin örgę̧mişi. https://art.asu.edu/content/marystokrocki sayfasında erişilmiştir.

Avcı Tuğal, S. (2018). Oluşum süreci içinde dijital sanat. İstanbul: Hayalperest.

Ballet Pixelle. Ballet Pixelle (2019). http://www.balletpixelle.org/ sayfasından erişilmiştir.

Bayraktutan-Sütçü, G.(2009). Dijital oyun çalışmalarında yöntem: Genel bir bakış. Binark, M., Bayraktutan-Sütçü, G. \& Fidaner, I. B. (Ed.), Dijital oyun rehberi, oyun tasarmı, türler ve oyuncu içinde (ss. 325-347). İstanbul: Kalkedon.

Bezir, Ç. (2012). "Second Life" ortaminda tasarlanan yabanc dil eğitimi: Öğretmen-ögrenci ve ortam etkileşimi. (Yüksek lisans tezi). https://tez.yok.gov.tr sayfasından erişilmiştir. 

doi:10.14687/jhs.v17i2.5769

Bulu, S. T, ve İşler, V. (2011). Second Life ODTÜ kampüsü. Akademik Bilişim 2011 Kongre'sinde sunulmuş bildiri, İnönü Üniversitesi, Malatya. http://ab.org.tr/ab11/bildiri/248.pdf sayfasından erişilmiştir.

Burgess, M.L., Slate, J.R., Rojas-LeBouef, A. ve LaPrairie, K. (2010). Teaching and learning in Second Life: Using the community of inquiry (COI) model to support online instruction with graduate students in instructional technology. Internet and Higher Education, 13(1-2), pp.84-88.

Retrived

from

http://edtc6325cooperativeproject.pbworks.com/f/teaching $\% 20$ and $\% 20$ learning $\% 20 \mathrm{in} \% 2$ 0SL \%20in \%20higher\%20ed.2010.pdf

Bülbül, H. (2016). Görsel sanatlar eğitiminde alternatif bir öğretim ortamı olarak Second Life. Demirel, Ö., Dinçer, S.(Ed.) Eğitim bilimlerinde yenilikler ve nitelik arayışı içinde (ss.1003-1016). Ankara: Pegem

A. http://www.pegemindeks.net/index.php/Pati/article/view/9786053183563b2.062/978605 3183563b2.062 sayfasından erișilmiștir.

Can, T. (2012). Yabanc1 dil öğretimi bağlamında öğrenen özerkliğinin sanal öğrenme ortamları yoluyla desteklenmesi. İstanbul Üniversitesi, Hasan Ali Yücel Eğitim Fakültesi Dergisi. 17, (2012-1), $72-85$. http://dergipark.ulakbim.gov.tr/iuayefd/article/download/1023017931/1023017168 sayfasından erişilmiştir.

Canbek, N.G. (2009). Üniversite-toplum işbirliüinde ögrenen-ders yöneticisi etkileşimi: Second Life (SL) üzerine bir çalşsma. (Yüksek lisans tezi). https://tez.yok.gov.tr sayfasından erişilmiştir.

Ceylan Dadakoğlu, S. (2018). Sanat ve tasarım eğitiminde sanal ortamın yaratıcıllğa etkisi (Second Life Örneği). (Doktora tezi).

Clark, R.C. \& Mayer, R.E. (2011). E-learning and the science of instruction. USA: Pfiffer, http://onlinelibrary.wiley.com/book/10.1002/9781118255971?doi=10.1002\%2F9781118 255971 sayfasindan erişilmiştir.

Coffman, T. \& M. B. Klinger (2008). Utilizing Virtual Worlds in Education: The Implications for Practice. International Journal of Social Sciences, 2(1), 29-33. http://citeseerx.ist.psu.edu/viewdoc/download?doi=10.1.1.124.93\&rep=rep1\&type=pdf sayfasından erişilmiştir.

Çepni, S. (2007). Araştırma ve proje çalışmalarma giriş.Trabzon: Celepler.

Çetin, E. (2013). Dijital oyunların geleceği. Ocak, M., A. (Ed.), Eğitsel dijital oyunlar, kuram, tasarm ve uygulama içinde (s.232-248). Ankara: Pegem A.

Çoban, M., Kalkan, A., Hınısoğlu, F. (2017). 3B sanal dünyalar ve kullanım alanları. Y. Göktaş (Ed.). 3 Boyutlu sanal dïnyalarn eğitimde kullanım içinde (s. 1-24). Ankara: Pegem A.

Dalgarno, B. \& Lee, M.J.W. (2010). What are the learning affordances of 3-D virtual environments? British Journal of Educational Technology, 40(6), 10-32. Retrieved from https://onlinelibrary.wiley.com/doi/pdf/10.1111/j.1467-8535.2009.01038.x

$\begin{array}{lllll}\text { DC } & \text { Spensley } & \text { Studios } & \text { Dan } & \text { Coyote }\end{array}$ http://www.dcspensley.com/art/?portfolio=lime-shuffle sayfasından erişilmiştir.

Dickey, M. D. (2003). Teaching in 3D: Pedagogical Affordances and Constraints of 3D Virtual Worlds for Synchronous Distance Learning. Distance Education, 24(1), 105-121. Retrieved from http://citeseerx.ist.psu.edu/viewdoc/download?doi=10.1.1.572.9740\&rep=rep1\&type=pd $\underline{\mathrm{f}}$

Dickey, M. D. (2005). "Three-dimensional virtual worlds and distance learning: two case studies of ActiveWorlds as a medium for distance education." British Journal of Educational Technology 36(3), 439-451. Retrieved from http://cyber.scihub.tw/MTAuMTExMS9qLjE0NjctODUzNS4yMDA1LjAwNDc3Lng=/10.1111\%40j.1 467-8535.2005.00477.x.pdf 
Ceylan Dadakoğlu, S., \& Aksoy, Ş. (2020). Title in article's language. Journal of Human Sciences, 17(2), 485-512. doi:10.14687/jhs.v17i2.5769

Dinçer, G. D. (2008). Sanal dünyalarn uzaktan eğitim danısmanlık hið̧metlerinde kullanmm: Second Life örneği. (Yüksek lisans tezi). https:// tez.yok.gov.tr sayfasından erişilmiştir.

Doğan, D. , Göktaş,Y. , Küfrevioğlu, R. \& Reisoğlu, İ. (2011, Eylül). Sanal ortamlarn eğitim amaģh kullanulabilirliğinin değerlendirilmesi. 5th International Computer \& Instructional Technologies Symposium' unda sunulmuş bildiri, Fırat Üniversitesi, Elazığ. http://web.firat.edu.tr/icits2011/papers/27803.pdf sayfasından erişilmiştir.

Duncan, I., Miller, A., Jiang, S. (2012). A Taxonomy of Virtual Worlds Usage in Education. British Journal of Educational Technology, 4 43(6), 1-17. https://www.researchgate.net/publication/230538897_A_taxonomy_of_virtual_worlds_us age in education sayfasından erişilmiştir.

Glyph Graves. Virtual Art Initative, Advancing The Art Of The Virtual Worlds (2009). bttp:// wmw.virtualart-initiative.org/Virtual Art Initiative/artists/Ghph.btml sayfasindan erisilmiştir.

Google Sheets (2019). Second Life'ta yer alan eguitim alanlarna genel bir bakess. https://docs.google.com/spreadsheets/d/1X4MnTFD87zFKK0zoSL8Ac_NxjvsA2o7KQ

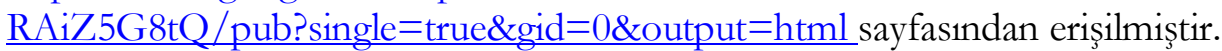

Göktaş, Y. (Ed.), (2017). 3 Boyutlu sanal dünyalarn eğitimde kullanımı. Ankara: Pegem A.

Gül, L. F. (2011). İşbirlikli mimari tasarım eğitiminde sanal dünya kullanımı. METU JFA, 28(2), 255-267. http://jfa.arch.metu.edu.tr/archive/0258-5316/2011/cilt28/sayi 2/255-267.pdf sayfasından erişilmiştir.

Gül, L. F., Gu, N. \& Williams A. (2007). A new approach to desıgn education: evaluations of 3D virtual worlds on design teaching and learning. Paper presented at the 7 th International Conference on Construction Applications of Virtual Reality, University of Newcastle, Australia, October 2007.

Retrieved

from https://pdfs.semanticscholar.org/b92d/4c53b225ba8e0ed104500667f764e47d80a3.pdf

Han, H. C. (2009). From 2D to 3D, Second Life, an alternative platform for e-learning. Taiwan, Taipei: PNC conference. Retrieved from 10 May 2019. https://www.academia.edu/34343469/From 2D to 3D Second Life an alternative pla tform for_e-learning_Functions of 2D_e-learning_platform

Han, H. C. (2015a). Gamified pedagogy: From gaming theory to create a self-motivated learning environment in studio art. Studies in Art Education. 56(3). 257-267. Retrieved from 10 May 2019.

https://www.academia.edu/27657479/Gamified pedagogy From gaming theory to crea te a self-motivated learning environment in studio art

Han, H. C. (2017). Virtual world and creativity Journal of Virtual Studies 8 (2), 12-22. Retrieved from https://www.academia.edu/34342626/Virtual world and creativity

Harrison, R. (2009). Excavating Second Life cyber- archaeologies, heritage and virtual Communities, Journal of Material Culture. 14(1), 75-106. http://cyber.scihub.tw/MTAuMTE3Ny8xMzU5MTgzNTA4MTAwMDA5/10.1177\%4013591835081000 09.pdf

Hew, F. K. \& Cheung, W. S. (2008) Attracting student participation in asynchronous online discussions: A case study of peer facilitation. Computers \& Education 51, pp.1111-1124. Retrieved from http://cyber.scihub.tw/MTAuMTAxNi9qLmNvbXBlZHUuMjAwNy4xMS4wMDI=/10.1016\%40j.comp edu.2007.11.002.pdf

Humanities Commons. Garrett Lynch (2019.) https://hcommons.org/members/garrettlynch/ sayfasından erişilmiştir.

Inman, C., Wright, V. H., Hartman, J. A. (2011). Use of Second Life in K-12 and Higher Education: A Review of Research. Turkish Online Journal of Distance Education-TOJDE, 12(3), 67-85. $\quad$ http://tojde.anadolu.edu.tr/yonetim/icerik/makaleler/1086-published.pdf sayfasından erişilmiştir. 
Ceylan Dadakoğlu, S., \& Aksoy, Ş. (2020). Title in article's language. Journal of Human Sciences, 17(2), 485-512. doi:10.14687/jhs.v17i2.5769

İstanbul Üniversitesi Second Life (2017). Neler yapulabilir? http://www.iusanalkampus.com/neleryapilabilir.php sayfasından erişilmiştir.

Jacka, L. (2010). Virtual arts: Visual arts education in the virtual world of Second Life. Journal of Art Education Australia, 33(2), 128-143. http://www.academia.edu/1355000/Virtual Arts Visual arts education in the virtual w orld_of Second_Life sayfasindan erişilmiştir.

Jennings, N.,\& Collins, C. (2007). Virtual or virtually u: educational institutions. International Journal Of Social Sciences, 2(3), 180-186. https://www.researchgate.net/profile/Nancy_Jennings/publication/292156918_Jenning s_N Collins C 2008 Virtual or virtually U Educational institutions in Second Life International_Journal_of_Social_Sciences_23_180186/links/56ab9dbf08ae8f386569c47d.pdf

Kayabaşı, Y. (2005). Sanal gerçeklik ve eğitim amaçlı kullanılması. The Turkish Online Journal of Educational Technology, 4(3), 151-158. http://www.tojet.net/articles/v4i3/4320.pdf sayfasından erişilmiştir.

Kluge, S. \& L. Riley (2008). Teaching in Virtual Worlds: Opportunities and Chanllanges. Issues in Informing Science and Information Technology, 5(5), 127-135. Retrieved from http://proceedings.informingscience.org/InSITE2008/IISITv5p127-135Kluge459.pdf

Koçak, Ö., Demirel, T., Karakuş, T., Göktaş, Y. (2016). Sanal Dünyalarda Kullanılan Öğretim Stratejileri, Yöntemleri ve Teknikleri. e - Kafkas Eğitim Arastormalar Dergisi, 3(2), 40-49. http://dergipark.gov.tr/download/article-file/226358 sayfasından erişilmiştir.

Kuksa, I. \& Childs M. (2014). Making sense of space-The desing and experience of virtual spaces as a tool for communication. UK: Oxford Chandos, http://dx.doi.org/10.1504/IJART.2011.043447 sayfasından erişilmiştir.

Linden Lab (2019). Oculus Rift SANSAR. https://www.lindenlab.com/about sayfasindan erişilmiștir.

Mamur, N. (2014b). Post-modernizmin sanat eğitimine yansıma biçimleri: görsel kültür ve eleştirel pedagoji, Ahi Evran Üniversitesi Kırşehir Eğitim Fakültesi Dergisi, 15 (2), 59-77. http://kefad.ahievran.edu.tr/InstitutionArchiveFiles/f44778c7-ad4a-e711-80ef00224d68272d/d1a3a581-af4a-e711-80ef00224d68272d/Cilt15Sayi2/JKEF $1522014 \quad 59$ 77.pdf sayfasından erişilmiştir.

Mikropoulos, T. A., \& Bellou, J. (2006). The Unique Features of Educational Virtual Environments. In P. Isaias, M. McPherson \& F. Banister (Eds.) Proceedings e-society 2006, International Association for Development of the Information Society (pp.122-128). Greece: IADIS. Retrived

from https://www.researchgate.net/publication/268378370_The_Unique_Features_of_Educati onal Virtual Environments/download

Nebulosus Severine (2017). Artist bttp://mmw.nebulosus-severine.com/new-media.btml sayfasindan erişilmistir.

Niemi H. , Harju V. , Vivitsou M., Viitanen K., Multisilta J. , Kuokkanen A. (2014). Digital Storytelling for 21st-Century Skills in Virtual Learning Environments. Creative Education, 5, 657-671. Retrieved from http://file.scirp.org/pdf/CE 2014052611292960.pdf

Ocak, M., A. (2013). Eğitsel dijital oyunların eğitimde kullanımı. M., A. Ocak, (Ed.), Eğitsel dijital oyunlar, kuram, tasarm ve uygulama içinde (s. 50-67). Ankara: Pegem A.

Ondrejka, C. (2004) Escaping the gilded cage: user created content and building the metaverse. New York Law School Law Review, Forthcoming., 49(1), 81-101. Retrieved from https://poseidon01.ssrn.com/delivery.php?ID $=74409102608209700508001100511909001$ 412104906205206408209500306611907002301110206409904306001001103900811809208 $\underline{308503112006610700201200305807312410808800312400703403802007212508208109707}$ $9025106026092107113070005007126102084010092110079098069126029 \& \mathrm{EXT}=$ pdf 
Ceylan Dadakoğlu, S., \& Aksoy, Ş. (2020). Title in article's language. Journal of Human Sciences, 17(2), 485-512. doi:10.14687/jhs.v17i2.5769

Özsoy, V. (2003). Görsel sanatlar eğitimi: Resim-is eğitiminin taribsel ve düş̈̈nsel temelleri. Ankara: Ümit Ofset.

Scope Claver. Flicker (2008). https:// wnw.flickr.com/photos/gracemcdunnough/2321423183 sayfasindan erişilmiştir.

Second Life (2018). Second Life, en iyi uygulamalar ögrenme ve 3B nesneler, deneyimler, topluluklar ve daha fazlasm yaratma bakkenda birçok bilgiyi paylașmaya da imkân vermektedir. http://go.secondlife.com/landing/creator/tr/?lang=tr sayfasından erişilmiştir.

Second Life (2018). Second Life'a üyelike bedelleri. https://secondlife.com/premium/ sayfasindan erișilmiștir.

Second Life (2019). Eğitim görseli. http://go.secondlife.com/landing/education/tr/?lang=tr sayfasından erişilmiştir.

Second Life (2019). Second Life'ta eğitimle ilgili etkinlikler yapma olanağr. http://go.secondlife.com/landing/education/tr/?lang=tr sayfasından erişilmiştir.

Second Life (2019). Second Life'ta güvenli kampüsler. http://go.secondlife.com/landing/education/tr/?lang=tr sayfasından erişilmiştir.

Second Life Avatar görsellerinden bir örnek. http://go.secondlife.com/landing/avatar/ sayfasindan erişilmiştir.

Second Life Community (2019). Second Life bilgi taban. https://community.secondlife.com/knowledgebase/english/sayfasından erişilmiştir.

Second Life Grid Survey (2018). Region Database (Second Life'ta aktif kullamu sayısi) http://www.gridsurvey.com/economy.php sayfasından erişilmiştir.

Second Life'ın milyoneri. Anshe Chung. http://www.sweetmoments.typepad.com/sweet moments/page/4/sayfasından erişilmiştir.

Second Life Turkey (2018). Second Life ekonomisi, toprak ve serbest piyasa üzerine kurulu bir ekonomidir.http://slturkey.com/faq.php?cat_id=1 sayfasından erişilmiştir.

Second Life Wiki (2019). Second Life bünyesinde sanal kampüs kuran üniversiteler. http://wiki.secondlife.com/wiki/Second Life Education/Resources sayfasindan erişilmiştir.

Second Life Wiki (2019). Second Life bünyesindeki müzeler. http://wiki.secondlife.com/wiki/Second_Life_Education/Resources_sayfasindan erişilmiştir.

Second Life Wiki (2019). Second Life Education. http://wiki.secondlife.com/wiki/Second_Life_Education/Resources sayfasindan erişilmiştir.

Second Life Wiki (2019). Second Life ögrenebilmek Second Life Wiki’nin video eğitimlerinden faydalanma. http://wiki.secondlife.com/wiki/Video_Tutorials 2019 sayfasından erişilmiştir.

Second Life Wiki (2019). Teen Second Life. http://wiki.secondlife.com/wiki/History of Second_Life sayfasından erişilmiştir.

Shanken, E.A. (2003) From cybernetics to telematics: the art, pedagogy, and theory of Roy Ascott. In. E.A. Shanken (Ed.), Telematic embrace: visionary theories of art, technology and consciousness. (pp.1-95). Berkeley: University of California. https://zaklynsky. files.wordpress.com/2013/10/telematic-embrace-visionary-theories-ofart-technology-and-consciousness-by-roy-ascott.pdf sayfasından erişilmiştir.

Sherblom, J. C., Withers, L. A. \& Leonard, L. G. (2009).Communication challenges and opportunities for educators using Second Life. In C. Wankel, \& J. Kingsley (Eds.), Higher education in virtual world: Teaching and Learning in Second Life (pp. 2946). UK: Emerald.

Smart, J., Cascio, J., \& Paffendorf, J. (2007). Metaverse” kavramı, üc boyutlu sanal dünya öngörüsü olarak fizilesel dünyanm nesnelerini, ara yü̈lerini, ağlarm sanal ortamm inşa eden ve onlarla etkileşimi sağlayan bir öngörü olarak anlam kąanmısttr. http://www.metaverseroadmap.org/overview/index.html sayfasindan erişilmiştir. 
Ceylan Dadakoğlu, S., \& Aksoy, Ş. (2020). Title in article's language. Journal of Human Sciences, 17(2), 485-512. doi:10.14687/jhs.v17i2.5769

Snow Crash'in siberpunk "gerçek" dünyasindaki "Büyük Hong Kong” metropolisinin Igor Sobolevsky firçasından bir illüstrasyonu. Manisal, A. (2016). Neal Stephenson - 2: Snow Crash ve Metaverse. http://her-an.org/2016/07/neal-stephenson-2/ html sayfasından erişilmiştir.

Soyseçkin, İ., (2007). Siberuzamda Bir Dünya: MUD’larda Toplumsal Cinsiyetin Şekillenişi. Folklor Edebiyat Dergisi, 50(13), 25-40. https://dijitaloyun.files.wordpress.com/2009/01/fe3.pdf sayfasindan erişilmiştir.

Star Journey. Gleman Jun (2019). http://www.star-journey.com/artists/gleman-jun sayfasindan erişilmiştir.

Stokrocki, M. (2011). Visual arts and multiliteracies in a digital age. Part of NAEA report: Learning in a Visual Age: The Critical importance of Visual Arts Education. National Art Education Association: Reston, $V A$. Retrieved from http://www.arteducators.org/advocacy/whitepapers

Stokrocki, M. (2011). Visual arts and multiliteracies in a digital age. Part of NAEA report: Learning in a Visual Age: The Critical importance of Visual Arts Education. National Art Education Association: Reston, VA. Retrieved from http://www.arteducators.org/advocacy/whitepapers

Sweet Moments (2007). Second Life'm ille milyoneri Anshe Chung [Resim]. http://www.sweetmoments.typepad.com/sweet_moments/page/4/_sayfasindan erişilmiştir.

Şahin, S. (2010). Dijital devrim ile birlikte sanatta mekan, beden, algi değişimi. (Sanatta yeterlilik tezi. https:/ / tez.yok.gov.tr sayfasindan erişilmiştir.

Tasa, U. B. (2009). İceriği kullamuclar tarafindan olusturulan 3 boyutlu sanal dünyalarda sanat ve mimari tasarm: Second Life® üzerine bir vaka çalısması. (Yüksek lisans tezi). https://tez.yok.gov.tr sayfasından erişilmiştir.

Taylor, L. \& Parsons, J. (2011). Improving Student Engagement. Current Issues in Education, 14(1), 133. https://cie.asu.edu/ojs/index.php/cieatasu/article/view/745/162 sayfasindan erişilmiştir.

Tokel, S. T., Topu, F. B. (2017). 3B sanal dünyalar ve kullanım alanları. Y. Göktaş (Ed.). 3 Boyutlu sanal dünyalarn eğitimde kullanım içinde (s. 1-24). Ankara: Pegem A.

Türk Dil Kurumu Avatar. http://www.tdk.org.tr/index.php?option $=$ com bati\&arama $=$ kelime\&guid $=$ TDK.BATI.5c abaf4c2e6799.24732848

University of Salford. AngryBeth Shortbread (2019). https://www.salford.ac.uk/arts-media/ourstaff/arts-media-academics/annabeth-robinson sayfasından erişilmiştir.

Uzun, K. \& Aydın, C. H. (2012). Kullanıcı profilinin ve bireylerarası ilişkilerin gerçek yaşamla karşılaştırllmasi: Second Life örneği. Eskeişebir Osmangaz̨i Üniversitesi İ̈BF Dergisi, 7(2), 263290. http://iibfdergi.ogu.edu.tr/makaleler/10251314_7_7-2_Makale_12.pdf sayfasindan erişilmiştir.

Uzun, K. (2011). Second life sanal yașam dünyasında kendini sunum davranıslarmm belirlenmesinde etnografik bir yaklaşım. (Doktora tezi). https://tez.yok.gov.tr sayfasından erişilmiştir.

Wang, Y. \& Braman, J. (2009). Extending the Classroom through Second Life. Journal of Information Systems Education, 20(2), 235-247. https://www.researchgate.net/publication/234165966 Extending the Classroom throu gh Second Life sayfasindan erişilmiştir.

Warburton, S. (2009). Second Life in higher education: Assessing potential for and the barriers to deploying virtual worlds in learning and teaching. British Journal of Educational Technology, 40(3),

414-426.

https://pdfs.semanticscholar.org/372a/dac03694428a89049752af41675a38a9e200.pdf sayfasından erişilmiştir.

Wikipedia (2019). Second Life Sanat yaymlar. http://www.wikizeroo.net/index.php?q=aHR0cHM6Ly9lbi53aWtpcGVkaWEub3JnL3dpa 2kvQXJ0c19pb19TZWNvbmRfTGlmZSNTZWNvbmRfRnJvbnQ sayfasından erişilmiştir. 
Wilson, B. (2011). Living in Actual and Digital Visual Worlds: One Big Goal for Art Education. Part of NAEA report: Learning in a Visual Age: The Critical importance of Visual Arts Education. National Art Education Association: Reston, VA. Retrieved from http://www.arteducators.org/advocacy/whitepapers

Zagami J. (2007). Second Life as an Arts Education Environment. Paper presented at ISTE 2010 (International Society of Tecnology in Education), Denver, CO. Retrieved from http://www98.griffith.edu.au/dspace/bitstream/handle/10072/26069/57706 1.pdf

\section{Extended English Summary}

Due to the rapid development of technology, many environments, tools and methods are being developed in the area of education and training. These innovations include education in virtual worlds and three-dimensional education technologies that we have encountered frequently in recent years. With the improvement of three-dimensional educational technologies, it is known that learning in 3D virtual worlds comes to the fore. Therefore, it is mentioned that virtual environments are used in all levels of education, learning and teaching process. Virtual worlds as a teaching and learning environment are said to be very comprehensive and a new experience that can be motivating for many students. It is also said that complex teaching strategies are said to be very suitable for the virtual world. (Jacka, 2010, p.138).

In this study, the virtual world of Second Life, which is a 3D, online life simulation and can be defined as an alternative teaching environment, is examined. Second Life is a multiuser, 3D, online application that reflects the latest stages of computer-mediated communication technologies. It allows users to create an alternative and ideal other world, interact with other people as they do in real life, and pursue behaviors alike to the real world within the advanced visuals presented. Second Life differs from other virtual online enviroments with its visually rich three-dimensional content with its features such as users can listen to the music they want, engage in entertaining activities, take on the roles they want, earn money, enter adventure with various races, improve their foreign languages. (Uzun and Aydin, 2012, p.265).

The aim of this article is to present Second Life, one of the virtual environments that can be used in art and design education, to provide a theoretical perspective on this subject, to contribute to the researchers and teachers who would like to use $3 \mathrm{D}$ virtual worlds for educational purposes and to create a theoretical basis for the researches to be conducted in this environment. In this study, a theoretical-analytical method has been used by focusing on the relevant literature within the framework of descriptive scanning method. Descriptive studies are usually carried out to illuminate a given situation, to make evaluations in accordance with the standards and to reveal the relations between the events. (Çepni, 2007, p.34).

In this research, first of all, the development of electronic and digital technology from the end of the 20th century was examined and its relationship with education has been questioned. In the context of the findings obtained from recent written sources and examples in the area of art education in the international context, the ways in which virtual worlds and Second Life virtual world are used in education and especially in art and design education have been tried to be examined. Therefore, 3D virtual worlds have been examined from a general perspective. Then, the Second Life application from 3D virtual environments has been examined in detail and its general characteristics have been defined.The use of Second Life in education has been discussed based on the opinions of the researchers.

Everything in Second Life; original experiences, interactive 3D objects, worldwide communities and more are created by users. In this study, it has been mentioned how construction and content creation done within Second Life application. Virtual reality offers a new aesthetic option and a new perspective on art (Akin transfer from Krueger, 2015). 
The three-dimensional design tools and scripts in Second Life have enabled Second Life to be used as a enviroment for artists to express themselves. In Second Life, prominent examples of art and design have been presented and examples of artists using the Second Life application have been given. Second Life provides a rich environment for constructive learning, socialization, research and exploration. In education such a virtual environment allows learners to demonstrate skills and strategies for using technological tools, visual design and innovations in the threedimensional environment. This virtual environment has great potential especially for distance learners. (Burgess, Slate, Rojas-LeBouef and LaPrairie, 2010, p.84).

Stokrocki (2011) stated that digital media created using electronic communication tools surrounds us as a paradigm shift in education. Stokrocki, who said the potential of digital worlds in art teaching would be immense in near future, discussed the usability of Second Life in art education (ASU, 2019). In this context, the subject of art education in Second Life has been discussed and the educational applications of Second Life in art and design education have been discussed.

In the discussion part, with the development of computer technologies and the use of virtual worlds in education, the achievements that can be obtained in art classes have been included. It is inevitable that educational systems, methods, equipment will be transformed depending on the age and technology. When the methods of art education are examined worldwide, it is seen that technology is included in education. Consequently, it has been said that the use of technology, various computer applications, 3D virtual worlds, VR and augmented reality applications within the traditional art education approach and including all of these activities are important for today's art education gains. Therefore, it is stated that the ways in which Second Life virtual world and other $3 \mathrm{D}$ virtual environments, tools and applications are included in art education should be questioned.

Since today's young people are called digital indigenous, they cannot be considered independent from digital environments and digital environments can be preferred for many learning styles. It is suggested that virtual applications can be included in art education depending on technology and Second Life can be considered as an educational environment for art and design educators (Ceylan Dadakoğlu, 2018, p.299). As 21st century skills are considered, it is thought that virtual worlds and applications in educational institutions can be integrated and applied in both general education and art education. Therefore, it is necessary to include virtual worlds, teacher training and application examples that can be done in virtual worlds in the curriculum. 